\title{
Advanced Manufacturing: Technology Diffusion
}

December 1995
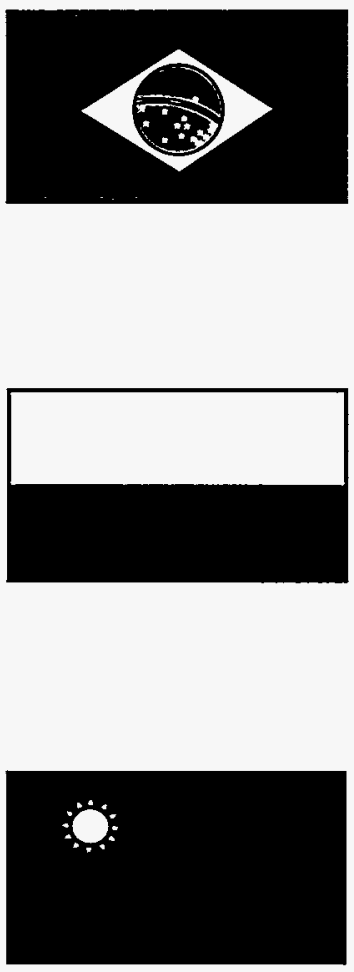

\section{MASTER}

DHETRRUTION OF THSS DOCWKENT IS UNLIAHTED a 


\title{
Advanced Manufacturing: Technology Diffusion
}

\author{
Aleta Tesar, Author
}

December 1995

This report has been prepared by the Lawrence Livermore National Laboratory, Nonproliferation, Arms Control, and International Security Directorate. The views expressed are those of the project personnel and not necessarily those of the Directorate or Laboratory.

\begin{abstract}
Disclaimer
This document was prepared as an account of work sponsored by an agency of the United States Government. Neither the United States Government nor the University of California nor any of their employees makes any warranty, express or implied, or assumes any legal liability or responsibility for the accuracy, completeness, or usefulness of any information, apparatus, product, or process disclosed, or represents that its use would not infringe on privately owned rights. Reference herein to any specific commercial products, process or service by trade name, trademark, manufacturer, or otherwise, does not necessarily constitute or imply its endorsement, recommendation, or favoring by the United States Government or the University of California. The views and opinions of authors expressed herein do not necessarily state or reflect those of the United States Government or the University of California and shall not be used for advertising or product endorsement purposes.
\end{abstract}

Work performed under the auspices of the U.S. Department of Energy by Lawrence Livermore National Laboratory under Contract W-4705-Eng-48.

For additional copies of this document, please FAX a written request to (510) 422-4563. 


\section{Contents}

Executive Summary .................................................................................... 1

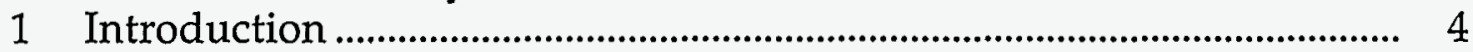

2 Diffusion Mechanisms .................................................................................... 6

2.1 Interaction Pathways........................................................................... 6

2.1.1 Communications .............................................................. 8

2.1.2 Experts ……......................................................................... 8

2.1.3 Acquisition …………………................................................ 9

2.1.4 Multinational ........................................................................ 10

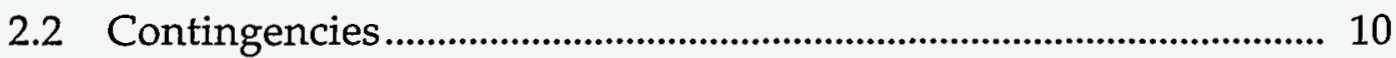

2.2.1 Technology Level .................................................................... 11

2.2.2 Economic Factors ................................................................... 11

2.2.3 Awareness of Emerging Technology .................................... 11

2.2.4 Government Efforts .............................................................. 11

3 Diffusion of Manufacturing Technologys .................................................. 11

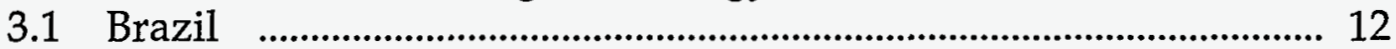

3.1.1 Technology Level .................................................................... 13

3.1.2 Economic Factors .................................................................... 14

3.1.3 Awareness of Emerging Technology ..................................... 14

3.1.4 Government Efforts................................................................ 15

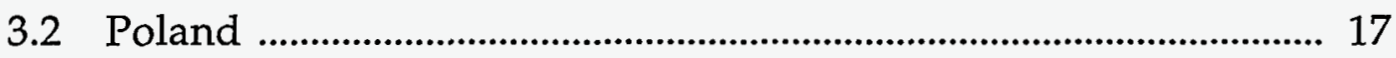

3.2.1 Technology Level ............................................................... 18

3.2.2 Economic Factors .............................................................. 19

3.2.3 Awareness of Emerging Technology …………...................... 20

3.2.4 Government Efforts ............................................................... 21

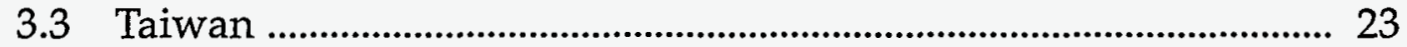

3.3.1 Technology Level .................................................................. 23

3.3.2 Economic Factors ................................................................... 24

3.3.3 Awareness of Emerging Technology ..................................... 25

3.3.4 Government Efforts ............................................................. 26

4 Examination of One Industry: Automobiles.............................................. 29

4.1 Predominant Technology Diffusion Mechanism .............................. 29

4.1.1 Brazil ........................................................................... 29

4.1.2 Poland ................................................................................... 32

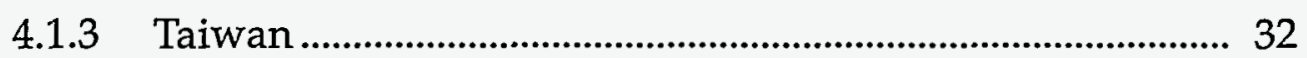

4.2 Technology Driver .............................................................................. 35

4.3 Automobile Industry Progression ....................................................... 36

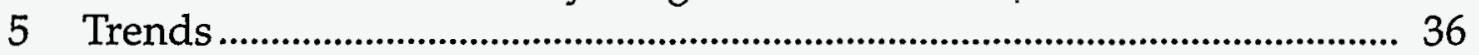

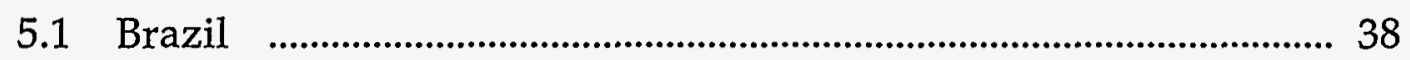

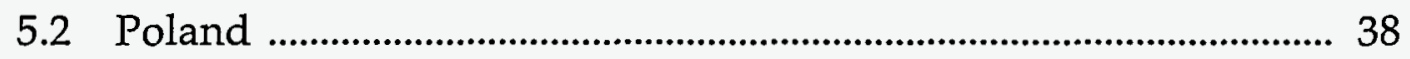

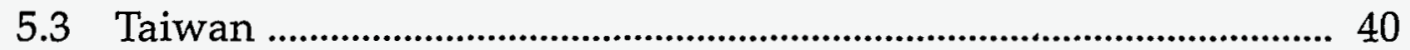

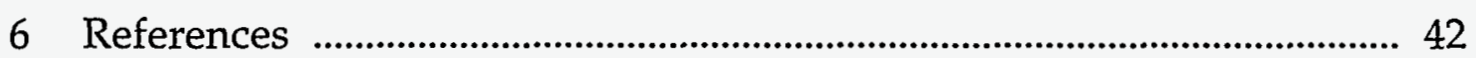




\title{
Advanced Manufacturing: Technology Diffusion
}

\begin{abstract}
Aleta Tesar
Executive Summary

In this paper we examine how manufacturing technology diffuses from the developers of technology across national borders to those ${ }^{*}$ who do not have the capability or resources to develop advanced technology on their own. None of the wide variety of technology diffusion mechanisms discussed in this paper are new, yet the opportunities to apply these mechanisms are growing. A dramatic increase in technology diffusion occurred over the last decade. The two major trends which probably drive this increase are a worldwide inclination towards "freer" markets and diminishing isolation.
\end{abstract}

Technology is most rapidly diffusing from the U.S. In fact, the U.S. is supplying technology for the rest of the world. The value of the technology supplied by the U.S. more than doubled from 1985 to 1992 (see the Introduction for details). History shows us that technology diffusion is inevitable. It is the rates at which technologies diffuse to other countries which can vary considerably. Manufacturers in these countries are increasingly able to absorb technology. Their manufacturing efficiency is expected to progress as technology becomes increasingly available and utilized.

The examination of the automobile industry in Brazil, Poland, and Taiwan indicates that the involvement of Multinational Enterprises (MNE) is crucial to technology diffusion. Joint ventures with MNE and stock ownership by MNE has become the norm. We also find that international standards and benchmarking are driving the need for technology improvements in both product design and in manufacturing. Because of increasing quality and performance requirements, the demand for and access to technology in the automobile industry is recognized as playing a major role in the development of a country's industrial infrastructure.

When factors which effect technology diffusion are examined, one conclusion stands out: government policies ${ }^{\dagger}$ dominate foreign investment levels, which primes the pump for technology diffusion. Gaining the capital to buy technology and technology-intensive equipment becomes

* Manufacturing in Brazil, Poland, and Taiwan are used as examples.

t Government policies of the nation receiving investment. 
paramount in raising manufacturing efficiency. Growing international competition to attract foreign investment means that government policies are increasingly scrutinized by foreign investors. These policies are sometimes tailored to acquire strategic technologies from MNE. Technology diffusion to Brazil (representing Latin America), Poland (representing Central and Eastern Europe), and Taiwan (representing the Asian Rim) were compared. Although the importance of technology diffusion to manufacturing in all three countries is recognized, prediction of the rates of technology diffusion to each of these countries is impossible for one major reason: their governments' industrial policies vacillate.

- Brazil: Manufacturing technology is conveyed to Brazil by multinational enterprises (MNE) and usually consists of established manufacturing methodology and equipment. Foreign-owned stocks and direct investment totaled $\sim \$ 40$ billion in 1992. Even so, it is the resistance to foreign technology indirectly fostered by the Brazilian Government which sets Brazil apart from Poland and Taiwan. Such opposition impedes technology diffusion and, consequently, will continue to delay industrial progress. We predict that Brazil is positioned for the most rapid technology diffusion and manufacturing growth of the three countries. The pivotal factor will be the current Brazilian Government's ability to reduce protectionist policies and effect a stable legislative environment.

- Poland: By far the dominant mechanism of manufacturing technology diffusion to Poland is through foreign direct investment by MNE upgrading existing industry. Polish industry is distinguishable from that in Brazil and Taiwan by the prevalent and incredibly low level of prior investment in manufacturing technology. It is estimated that only $5-6 \%$ of Polished manufactured goods use modern technologies. The Polish Government has not been seriously involved in foreign technology acquisition and diffusion although it is still the source of almost all R\&D funding. We suggest that technology diffusion into Poland will continue at a slow pace as foreign investment trickles in and Polish goods maintain privileged access to the E.U. market.

- Taiwan: Two main mechanisms of manufacturing technology diffusion to Taiwan stand out: technical assistance by MNE establishing manufacturing alliances in Taiwan and government institutes which access and develop available technologies specifically for high-tech spin-offs in strategic industries. In enterprises with more than 300 employees, $44 \%$ have received foreign investment. Manufacturing in Taiwan is facing an erosion of investment at home at a time when domestic technology innovation is just beginning to be commercialized. In general, the 
R\&D sector in Taiwan is judged to be too young to develop advanced manufacturing technologies indigenously without international support. The need for diffusion of advanced technology and related manufacturing equipment is expected to increase as Taiwan's production expands in Asia and competition increases in the years to come. A thriving entrepreneurial tradition combined with firm public support of education sets Taiwan apart from Poland and Brazil. 


\section{Introduction}

There has been long standing concern that the rapid diffusion of manufacturing technology across national borders is eroding national investment in technology and causing a "hollowing-out" of industry. Technology is most rapidly diffusing from the U.S. In fact, the U.S. is supplying technology for the rest of the world. Figure 1.1 presents the 1992 Technology Balance of Payments ${ }^{1}$ for several industrialized countries. [1.1,1.2] The technology balance of payments for the U.S. alone is $\$ 14.9$ billion. The sum of all countries shown except the U.S. is $\$-8.9$ billion. Beyond supplying these industrialized countries with technology, the difference between $\$ 14.9$ billion and $\$ 8.9$ billion indicates that the U.S. is supplying $\$ 6.0$ billion to other countries ${ }^{2}$. A dramatic increase in technology diffusion is obvious as the U.S. receipts for technology more than doubled from $\$ 8.7$ billion in 1985 to $\$ 19.9$ billion in 1992. [1.1] Technology acquisition through transfers is logical because technology development is risky, expensive, and requires specific experience which may not be available in some countries. [1.3] Gaining capital to buy technology and technology-intensive equipment becomes paramount in raising efficiency.

Manufacturing technology development is most advanced where cumulative investment in manufacturing is the highest. This environment builds technology competence. As manufacturing becomes more efficient, more wealth is generated. Manufacturing capability is quickly spreading to people who previously had little opportunity to generate wealth. This process is driven by the international investment of wealth. As the level of investment grows, the ability to access and apply technology also increases, leading to more efficient activity. [1.4] As a country's wealth increases, people become more highly educated and realize more opportunities for contributing to that society. In countries where economic opportunities for the individual are increasing, social revolution is shunned.

Three strong arguments are often given to promote free trade and relax fears regarding technology diffusion. First, when manufacturing

\footnotetext{
1 The Technology Balance of Payments is defined as the difference between receipts and payments for patents (purchase, sales), licenses for patents, know-how (not patented), models and designs, trademarks (including franchising), technical services, and finance of industrial R\&D outside national territory. It does not include commercial, financial, managerial, and legal assistance; advertising, insurance, transport, films, recordings, material covered by copyright, design, or software. [1.2]

2 The terms used to describe these other countries has varied over the years. In the 1970 s the term was "Newly Industrializing Economies"; in the 1980s, "Economies in Transition"; and in the 1990s, "Big Emerging Markets". As a colleague recently remarked, these countries stand out simply as poorer, having relatively low average investment in manufacturing technology. We will use the phrase Low Average Productivity (LAP) to describe average manufacturing in these countries.
} 


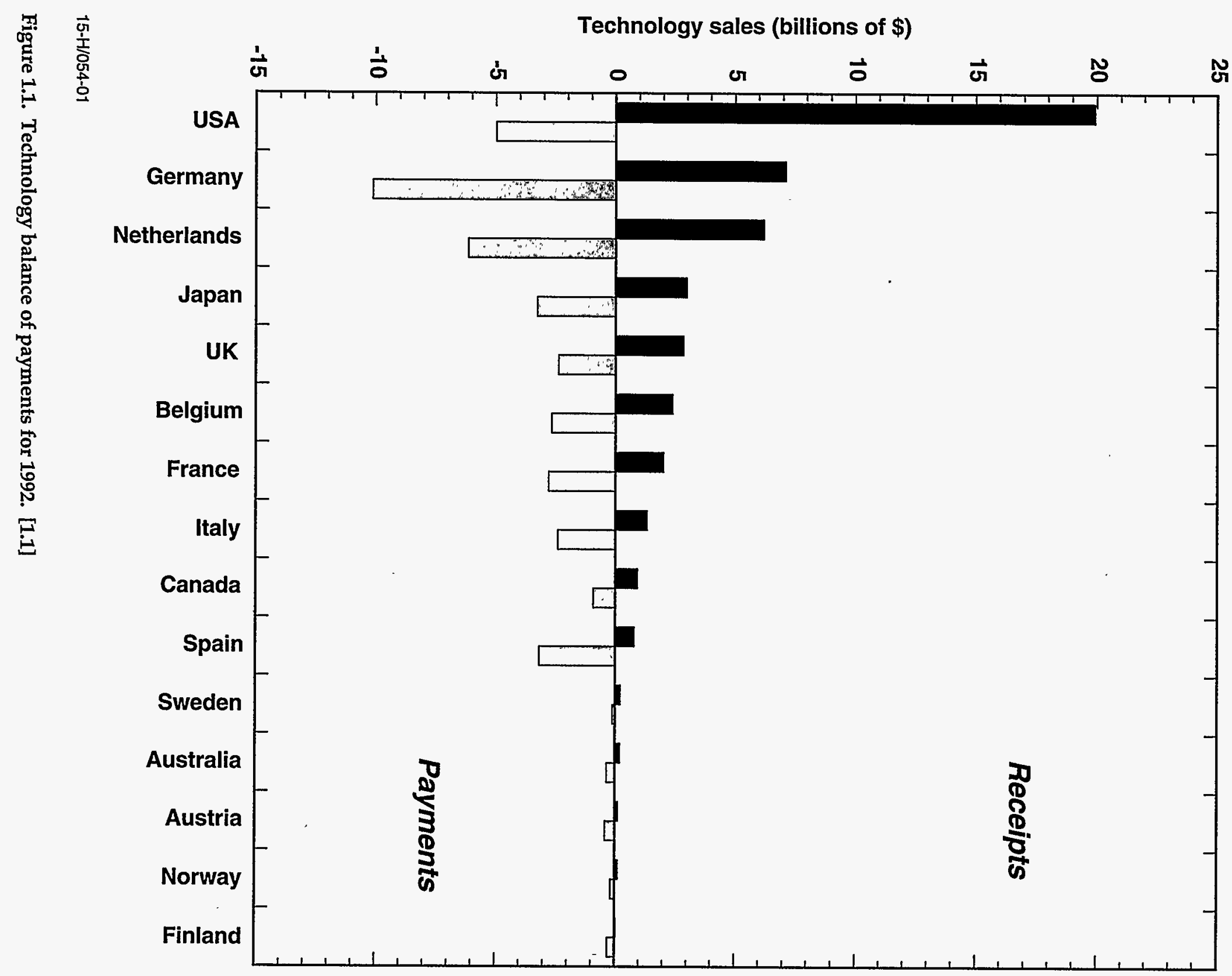


productivity is increased via technology while using lower wage labor, consumers receive the benefit of lower prices and competing companies are forced to find creative means of reducing their prices. Secondly, new market opportunities open with foreign manufacturing, such as supplying technical expertise and capital equipment for continuing upgrades for their facilities. [1.5] Third, companies rarely license their most advanced manufacturing technology, reserving their competitive edge. [1.6] The essential problem, however, really boils down to a question of do we trust the managers of our nation's companies to properly place value on technology which their company owns? Similarly, but somewhat separate from technology diffusion, is the fear that U.S. companies are not investing adequately in continuing technology development. Segments of foreign competition have taken up the slogan "out invest, hire the best". [1.7] History shows us that technology diffusion is inevitable. It is the rates at which technologies diffuse to different countries that vary considerably. In this assessment, technology diffusion will be examined using Brazil (representing Latin America), Poland (representing Eastern Europe), and Taiwan (representing an "Asian Tiger") as examples.

\section{Diffusion Mechanisms}

There are numerous pathways for technology diffusion, some of which have been identified and listed below. None of the wide variety of diffusion mechanisms are new, yet the opportunities to apply these mechanisms are growing. In this Section we attempt to categorize the main routes by which technology diffuses in order to demonstrate the variety of possible mechanisms. These routes are termed interaction pathways and are listed in Table 2.0 . This is not meant to be a conclusive list. Towards the end of the section a brief description of several factors which affect technology diffusion is included. These factors are used in contrasting country situations in Section 3. Due to the complexity of these factors, the international diffusion of technology cannot be controlled by regulation. Perhaps technology should be viewed as a commodity which is protected, used, and sold by the originator.

\subsection{Interaction Pathways}

We use the term interaction pathways to describe the routes by which technology is exchanged. Technology diffuses from those that have it through interactions with others. In this paper we are concerned with manufacturing technology diffusion from the developers of a technology 
Table 2.0. Interaction pathways

1. Communications

Internet/Phone/Fax

Trade Shows

Technical Publications

Visiting Delegations

2. Experts

Foreign Training

International Consultants

Universities \& National Laboratories

Support Laboratories

R\&D Centers (foreign)

3. Acquisition

Technology Licensing

Equipment Sales

Contract Engineering

4. Multinational corporations

Consortia

Joint Ventures

Transnational Alliances \& Coalitions
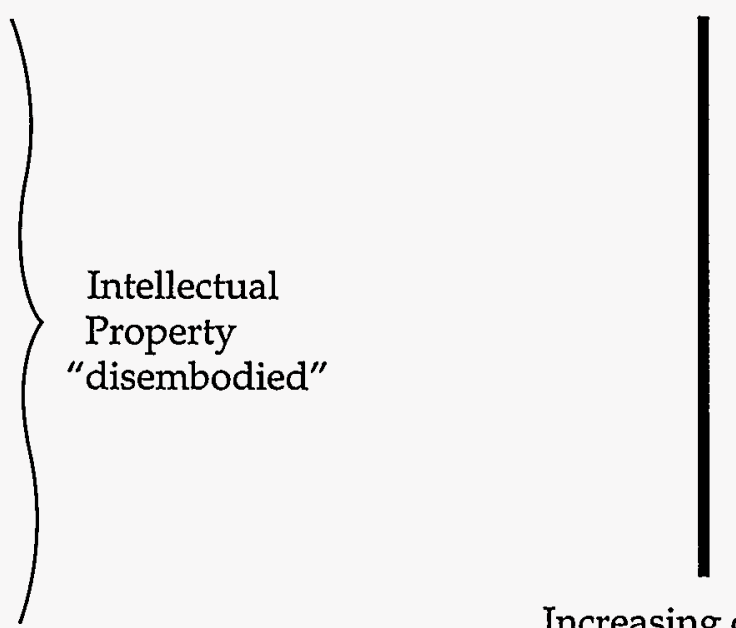

Increasing control of the technology
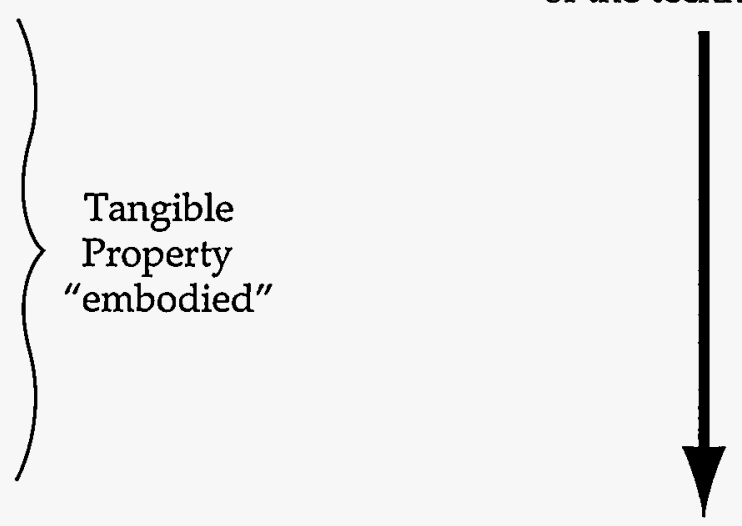
across national borders to those who do not have the capability or resources to develop the technology on their own.

\subsubsection{Communications}

This decade has seen an explosion in the rate of information transfer. The dissemination and decentralization of information is big business which transcends national borders. [2.1] The following means of technology communication are especially useful when addressing a particular technology problem.

Technical Publications: The numbers of international publications used by researchers to disseminate technology and to keep up with technology advances are increasing. Abstracting services and $C D / R O M$ libraries make benchmarking international technology in these publications much more efficient.

Internet/Phone/Facimile: Expansion of global telecommunications systems has permitted networking around the world. Ethernets and internet computer-based information handing techniques are providing prompt access to technology.

Trade Shows: International trade shows allow equipment manufacturers to demonstrate their latest products to potential customers. Concurrently, competing manufacturers can compare products. [2.2] These trade shows have continued to be important to suppliers of instruments and manufacturing equipment for more than a century. Technical short courses are given at trade shows to permit a quick update on specialized fields.

Visiting Delegations: Formal visits to foreign companies and laboratories are made to gain information on specific technological advances, future plans, and potential cooperation.

\subsubsection{Experts}

Experts are most effective in diffusing technology when manufacturing methods and "know-how" are desired.

Foreign Training: Training in foreign universities and experience working in foreign industries continue to be significant pathways for technology diffusion when these experts begin working in countries with low average productivity.

Visiting Expert Programs: Many large companies and national laboratories have found visiting expert programs to be useful in sharing research and development activities. 
Universities and National Laboratories: In working with domestic industries, universities and national laboratories (i.e., public institutions) are a major conduit for technology diffusion. The mission of some national laboratories is specifically to seek out foreign technology and disseminate that technology to industry. University and institute researchers must also be aware of foreign technology developments to properly assess the goals and impact of their projects. Researchers customize programs to particular companies, or as is becoming increasingly popular, contribute to industrial liaison programs. The hiring of students involved in these programs further contributes to technology diffusion. [2.3]

International Consultants: Technical consulting firms are expanding operations to foreign offices where temporary consulting services are needed to solve problems. [2.4]

Service Laboratories: Commercial service laboratories can provide technical analysis, information, and advice to manufacturing companies which do not have extensive R\&D facilities. Service laboratories maintain their reputations by awareness of the state-of-the-art technologies, equipment, and procedures, regardless of the origin.

RED Centers: Foreign-owned manufacturing companies often establish $R \& D$ centers in their locale. The major mission of these centers is usually to develop product designs oriented to the local market. This includes studying the competition. The opportunities which arise to interact in local technology development projects are usually welcomed by the parent company. [2.5]

\subsubsection{Acquisition}

A defined value is placed on established technology when it transfers from one party to another through the following means.

Licensing: Licensing agreements transfer technology in exchange for a fee (sometimes also through barter). Licensing occurs where patent rights are acknowledged.

Equipment Sales: Beyond being a large industry, the sales of instruments and production equipment to manufacturing enterprises is a decisive pathway for technology diffusion. Information regarding specialized adaptation and processing parameters which accompany the equipment is a major consideration for the buyer. This information is often conveyed in training manuals and on-site training programs.

Contract Engineering: International engineering companies build manufacturing facilities under contract. Such facilities range from updating processes to building state-of-the-art turn-key plants (e.g., chemical plants). 


\subsubsection{Multinational Enterprises}

Diffusion of technology between corporations and across national borders usually takes one of the following pathways. These are strategic agreements on technical cooperation between firms which tend to combine capabilities and assets.

Joint Ventures: In exploiting a new manufacturing technology or developing a new product technology, joint ventures provide cost and profit sharing. A new company is typically formed by the parent companies to concentrate on the technology and product manufacturing.

Consortia: Agreements for collective technology creation may form when a common goal is recognized. Sharing technology provides both access to expertise and risk sharing in research investment. Consortia are usually associated with research and development of "precompetitive" technologies. However, consortia may seek quality improvements in "mature" technology areas. The motives for the consortia change as the technology becomes more developed, sometimes becoming product development alliances. [2.3]

Product Development Alliances: Product development alliances share complementary capabilities of companies. Such alliances require that the products developed do not threaten the sales of each company's existing products. Access to process technology is a common goal; however, technology exchange is required for a successful alliance. [2.6] Product development alliances do not include consolidated manufacturing (as in joint ventures).

Transnational Coalitions/Mergers: Coalitions, acquisition, and mergers of companies provide an important means of technology diffusion. There are several reasons for transnational companies to make this investment (e.g., to form stable supplier/customer relationships, to enter a new technology area, to cut costs, to develop stable design/manufacturing links, etc.). In any of these cases, technology may flow to the acquired company to improve its competitiveness, and/or to the parent company to promote new business opportunities. [2.7] Much has been written on the technology exchange between supplier companies and their customers. [2.8]

\subsection{Contingencies}

There are prominent factors which influence technology diffusion. Although these factors have been studied in detail, they are almost impossible to quantify. [2.9] We group them into four categories. The categories are used in Section 3 to clarify and contrast technology diffusion in three countries. The four categories are Technology Level, Economic Factors, Awareness of Emerging Technology, and Government Efforts. 


\subsubsection{Technology Level}

Discussions of technology level can include dominant manufacturing industries, the maturity of those industries, the sizes of enterprises, and the tendency towards multinational enterprises. Innovative capability is loosely linked to technology level. It is thought that manufacturing technology level tends to begin with assembly (e.g., of "kits"), progresses to component manufacturing, and then evolves to the pursuit of $R \& D$ to design innovative production capabilities and products.

\subsubsection{Economic Factors}

The national economic status (especially labor costs), infrastructure integrity (especially of transportation and communications), the availability of investment financing (e.g., foreign direct investment), and the level of competition are major economic factors.

\subsubsection{Awareness of Emerging Technology}

Awareness of technology precedes adoption of that technology. The availability of communications, travel, experts, and training are fundamental to technology awareness.

\subsubsection{Government Efforts}

National goals and industrial policy influence market forces and the environment in which industry must operate. Government efforts usually include $R \& D$ programs to encourage technology assimilation. $R \& D$ can be enhanced by government investment or diminished by imprudent taxes.

\section{Diffusion of Manufacturing Technology}

Manufacturing technology diffusion to three countries with low average productivity (LAP) is examined in this section. Brazil (representing Latin America), Poland (representing Central and Eastern Europe), and Taiwan (representing the Asian Rim) were chosen for comparison. When factors which effect technology diffusion are examined for the three LAP countries, one conclusion stands out: government policies dominate foreign investment levels, which primes the pump for technology diffusion.

The governments of all three countries want to increase their nation's wealth. As Raymond Vernon stated "by 'industrial policy' they usually mean a set of official goals and related measures that distinguish among 
industrial sectors and even among firms, supporting one and restraining another in an effort to improve the performance of the economy as a whole." [3.0] All three governments have emphasized policies of import substitution, controlled domestic markets, and export subsidies. Import substitution is used to control home market spending (i.e., to prevent money from leaving the country). Domestic industry is protected by providing captive customers with the expectation that industry will prosper, enabling the industry to then compete globally. To hasten the competitiveness of domestic industry, subsidies are granted to particular exports. Government R\&D funding is used to encourage "high-tech" science as labor costs begin to rise and international competition becomes more intense.

The perversity of these policies is that they effect foreign investment which is critical to technology diffusion. Without foreign investment and exposure to foreign competition, infrastructure growth and technology development lag. Two other important features of government policies with respect to technology diffusion are their stability (i.e., the predictability of policies), and legislative action on intellectual property rights.

The dominant diffusion mechanisms are identified for Brazil, Poland, and Taiwan in this section. The accompanying discussion is based on the main factors affecting technology diffusion: technology level, economics, awareness of emerging technology, and government efforts.

\subsection{Brazil}

Manufacturing technology is conveyed to Brazil by multinational enterprises (MNE) and usually consists of established manufacturing methodology and equipment. The major incentive for MNE to expand into Brazil is access to the large and well protected Brazilian market with accompanying low labor costs. Education in foreign universities is a secondary avenue of technology diffusion. Brazil has not seriously invested in cutting-edge manufacturing technology. Instead, companies have been given a controlled market and little competition. Consequently, Brazil's technology base is inadequate to independently provide advanced manufacturing technology for indigenous industry. With import substitution and a closed domestic market as the major industrial policy goals, foreign investment and MNE were relied upon for manufacturing technology. [3.1] Even so, it is the resistance to foreign technology indirectly fostered by the Brazilian Government which sets Brazil apart from Poland and Taiwan. This resistance can be seen in the legislative and economic environment which is not conducive to technology diffusion. Although today there are efforts to change the legislative environment and to open markets, these efforts face 
significant opposition. The opposition will continue to impede technology diffusion and, consequently, will delay industrial progress.

\subsubsection{Technology Level}

A technology lag is prevalent in Brazilian manufacturing. Being a very large industrial complex with multinational concerns, a wide range of technical achievement and expertise exists. In general, however, the lag will require many years to overcome. Several Brazilian studies carried out in the 1980s noticed "slow uptake of new technologies and organizational techniques" even when companies were exposed to the manufacturing concepts. [3.2] The problem goes deeper then implementation. It has been stated that "this is not a matter of arguably 'luxury' expenditure on scholarly research, but something that goes to the heart of the country's innovative capacity. If no real efforts are being taken to increase technological activities in a broad and systematic way, we should not expect to see, in the next few years, changes in the present situation." [3.2]

Innovation: At the current time Brazilian industry has not clearly demonstrated innovation in advanced manufacturing technologies. Many business leaders are aware of this situation and consider it negative. As Jose Vargas, the Minister of Science and Technology, claimed: "Only by overcoming our technological backwardness shall we be equipped to compete with the economies of other countries... otherwise, we shall remain mere users of foreign technologies." [3.3] In other words, the use of technology packages which already exist elsewhere (i.e., turn-key manufacturing) is not making Brazil competitive. The concern is acute in claiming that the availability of such packages actually limits creativity. [3.4] There appears to be widespread resistance to technology assistance and manufacturing license (i.e., the not-invented-here syndrome). This resentment towards technology diffusion backfires to retard progress further. It also misses the point that Brazil's main competition is coming from other developing countries with inexpensive labor which take full advantage of foreign technology assistance as the present opportunity.

Globalization: Globalization of Brazilian manufacturing is unilateral. A large percentage of manufacturing production involves foreign participation. These MNE import best manufacturing practices and established manufacturing technologies (including equipment). It is the methodology (along with access to capital with lower interest rates) which encourage Brazilian companies to form alliances and joint ventures with foreign partners. Contribution to and participation in Brazilian R\&D activities by MNE has been identified by some Brazilians as less than satisfactory. [3.1,3.3,3.5] Increasing pressure on MNE to become involved in Brazilian R\&D can be expected in the future. 


\subsubsection{Economic Factors}

Status: The Brazilian economy is stabilizing under new government policies which are encouraging foreign investment. After steady growth and relative prosperity during the 1970 s, Brazil suffered prolonged inflation through the 1980s and early 1990s. Brazil hosts the largest industrial infrastructure in Latin America. The total 1993 investment (gross fixed capital formation) in the Brazilian economy was estimated at $19 \%$ of $\mathrm{GDP}^{3}$. [3.6] Manufacturing is important not only to the economy, but also in providing job opportunities which encourages social stability. It follows that the Brazilian Government is genuinely interested in supporting Brazilian industry. With 160 million people, Brazil is the most populous Latin American country. The market, however, is currently limited. Over 72 million citizens are considered impoverished by international standards. [3.7] Brazil's large labor pool and job scarcity will probably keep labor costs low for many years. As part of the current effort to reduce government deficit spending, some national corporations are being privatized and the Brazilian market is slowly opening.

Foreign Direct Investment (FDI): Foreign investment brings much needed capital, trade, and productivity to Brazilian manufacturing. The changing trade policy (i.e., especially tariff reductions) is starting to encourage foreign direct investment. Stocks comprise the vast majority of foreign investment. Direct investment in Brazilian companies is much smaller, reflecting the high risk associated with long-term investment in Brazil. [3.7,3.8,3.10] Investments in Brazil by the U.S. are the highest of any nation, totaling $\$ 16.9$ billion by the end of $1993 .{ }^{4}$ Japan and Germany also have significant investments in Brazilian industry. [3.11]

\subsubsection{Awareness of Emerging Technology}

Although Brazilian engineers are knowledgeable of advanced manufacturing technologies, they have very limited opportunities to work with them. A lag in technology compared with that in some foreign manufacturing is widely recognized in Brazil. The lag was pronounced an educational issue by the Brazilian Joint Congressional Investigative Commission. [3.4] It is our analysis that the issue is really improvidence by Brazilian industry due to the legislative and economic climate fostered by the Government. Resistance to advanced technologies is obvious. The difficulty experienced by engineering consulting firms in attempting to introduce $C A D^{5}$ systems is an example

3 This percentage of Gross Domestic Product is in the same range as most industrialized countries.

4 The total U.S. foreign direct investment in Mexico reached $\$ 16.375$ billion as of 1994 .

5 CAD stands for computer aided design which is often linked with CAM (computer aided manufacturing) for process automation. 
of the technology assimilation problem. [3.11] In this case, CAD systems were perceived as a tool for increasing manpower productivity. Public projects and national companies are the main clients of these firms. Labor productivity has not been a critical business factor in this climate.

However, the Brazilian educational system is in an unprecedented crisis. The crisis undermines the acceptance of new technology. Lack of resources has destroyed a once striving educational system, leading to very low average academic achievement. The emerging laborforce is characterized by an $80 \%$ school drop-out rate. Only 232 students out of 1000 who start school continue beyond the sixth grade, with 8 students out of 1000 finishing some form of higher education. [3.4] The general public does not recognize education as key to personal success.

Furthermore, high technology products are not a typical part of the life of most citizens. Few can afford refrigerators, and the value of personal computers or cellular telephones is not obvious.

This public indifference towards technology has caused long-term problems for technology assimilation. There is no precedent for symbiotic interaction between Brazilian industry and researchers at universities or research institutes: even in the 1960s they were not significant players in industrialization. Consequently, universities and national research institutes have difficulty in providing technology transfer to industry. Compounding the problem is a serious lack of resources which, as one observer states, "has led the public university system into a deflation of its aspirations for scientific and technical mastery and to an abdication of its competence." [3.4] High average productivity countries (e.g., the U.S., Japan, Great Britain, and Germany) have over four times as many engineers as a percentage of the population. [3.4] These numbers indicate a low level of educational activity in Brazil. The quality of university education appears to vary greatly. Most post-graduate studies are pursued abroad, some with government assistance. The salary policy for technical personnel at government research institutes has caused many researchers to leave. Government officials are encouraging the use of scientists from Central and Eastern Europe and the former Soviet Union to fill the gap. [3.3]

\subsubsection{Government Efforts}

In striving for greater technological autonomy, the policies of the Brazilian Government are not encouraging technology diffusion and in some respects are hindering international cooperation.

Goals: In 1990, the Brazilian Government announced that its major science and technology goal was "to restore the international competitiveness of Brazil's industry". [3.12] Accompanying this goal is the long standing desire to be respected in the global community as more than a third world country. Advanced technology is widely perceived as 
the key to both of these goals. The problem is that Brazil is not currently in a position to independently develop and utilize technology to achieve these goals. Both the economic and legislative climate undermine these goals. This situation may change in the near future if the Government can remain focused and continue to progress towards a free market economy. The benefits of importing manufacturing equipment incorporating technology (i.e., the use of investment by others to improve productivity or quality) is well recognized by the Brazilian government. [3.13] For this reason, tariffs on imported machinery have been recently removed to encourage technology diffusion.

Policy: The two main tenets of Government industrial policy, protectionism and increasing Foreign Direct Investment (FDI), are viewed to be at odds. There is an extremely strong belief in the necessity of protecting and "safeguarding" domestic industry from foreign competition. Keeping the domestic market captive is a large measure of this protectionism. At the same time, the lessons of the 1980s established that FDI is absolutely necessary for the survival of Brazilian industry. Other countries with low labor costs are also vying for FDI. The Government is carefully relaxing some restrictions to encourage FDI, while at the same time controlling the infrastructure to provide domestic industry with advantages.

A good example relating directly to diffusion of technology is the fight over intellectual property. The fact that certain technologies are protected internationally and controlled by the originators is viewed as a hindrance to Brazil's progress. Over $85 \%$ of patents granted in Brazil have been issued to foreigners. Popular rhetoric typically points out that "the development protected by patents is not ours." [3.4] The lack of real protection for technologies which MNE imported into Brazilian production facilities, or relied on for product success, is considered a serious concern for MNE assessing expansion into Brazil. Consequently, MNE do not typically participate in R\&D in Brazil as illustrated in the following quote. "On the aerospace front, Embraer and Northrup are involved in the joint primary aircraft training system (JPAT) but all of the R\&D for the project was completed earlier in the U.S. as was the research for a robotic welding system recently installed by GM at its plant outside of Sao Paulo. Both companies mentioned protection of their technology as the principle reason for conducting their research in the U.S. prior to the start of their projects in Brazil." [3.5]

From 1980 to 1993, the Brazilian Government ran an experiment in industrial protection intended to develop a domestic technology base in "informatics". The Brazilian market for personal computers and their peripherals was reserved for products manufactured with national technology. [3.4] Importation was prevented. This was an effort to reinvent the wheel in manufacturing, producing products to compete with those already on the international market. The experiment failed, demonstrating conclusively the disadvantages of technical isolation. 
This industrial policy not only protected industry by holding the Brazilian market captive, but attempted to develop technology in a vacuum. The resulting Brazilian products are expensive and typically of lower quality than found on the international market. Consequently the domestic market demand did not grow as anticipated. The National Informatics Policy did, however, provide technical training for a large number of Brazilians.

National RED Plans: There are few Brazilian R\&D projects because funding is limited. The Government is attempting to improve this situation. Two industrial R\&D programs were established in 1990: support for projects involving Quality and Productivity and support for projects involving Industrial Technological Capability. Little information on the projects is available. These programs are to channel R\&D funding through industry to academia to encourage domestic cooperation. [3.12] Although the projects may be effective in encouraging cooperation, it is suspected that the level of investment is insufficient to develop technology of much consequence.

A long-term commitment in technology investment has been absent for at least a decade. Expenditures on science and technology reached $\$ 2$ billion in 1985. [3.2] In 1994, the figure was $\$ 1.5$ billion. [3.4] The technology base of Brazilian industry is judged by Brazilians to be inadequate to compete in free markets as it "does not prompt the assumption that it would be capable of promoting a technological renewal to make the industry competitive on foreign markets, and even internally, in the event of a likely opening of the Brazilian market." [3.4] The percentage of GDP expended on science and technology is $\sim 0.8 \%$, over three times lower than in the U.S., and less than half the percentage of GDP spent in Taiwan. Government funds are supporting $94 \%$ of R\&D. [3.4] The Government enacted a substantial R\&D tax credit in 1993 to encourage industrial support of university projects in computer science and industrial production. This credit is only available to domestic companies. [3.3]

\subsection{Poland}

By far the dominant mechanism of manufacturing technology diffusion to Poland is through FDI by MNE upgrading existing industry. Access to protected European markets is the major incentive for FDI in Poland. Global communication channels are greatly improving technology awareness, yet technology application is sluggish. Industrial policy in Poland continues to be based on import substitution and subsidizing of exports. [3.1] The economic recession and lack of capital will delay Polish industry in achieving the average E.U. productivity level, and thereby competing in free markets. Polish industry is distinguishable from that in Brazil and Taiwan by the prevalent and incredibly low level of investment in manufacturing technology. There are no recognized 
industrial advantages in Poland and the domestic infrastructure is crumbling. Under current economic hardships and global competition, this legacy will take several decades to rectify.

\subsubsection{Technology Level}

The level of manufacturing technology in Poland is low. The Polish Central Office of Planning estimated that only 5-6\% of Polish goods are manufactured using modern technologies. To compete within the European economy at European labor costs, Polish industry is faced with the monumental task of leaping from low quality, labor-intensive production to efficient, high quality production. Advanced manufacturing technologies are critical to achieve this goal. Polish industry is facing this challenge at a time when many other nations are competing for the same market sectors.

Dominant Industry Type: Manufacturing in Poland is often referred to as "heavy industry": in this case representing the production of low and medium technology products. There is little product innovation. The large, typically state-owned companies produce raw materials in industries such as metals, fuel, chemicals, and textiles. The new, private manufacturers typically produce consumer goods (especially food, clothing, paper), and assemble machinery and electrical equipment. No examples are found of products which require cutting edge (i.e., advanced) manufacturing technologies, such products are imported. However, application of advanced manufacturing technologies are essential to improve product quality and production efficiency. Automation and integration of manufacturing processes are time and cost intensive endeavors. This investment is a problem for Polish manufacturing.

Maturity: The widespread realization of the Polish technology gap is aptly stated in the following: "The technology discrepancy between countries of free-market economy and post socialist countries was most clearly indicated in the Persian Gulf. Even though in the post socialist countries the most advanced technology and technical thought (available) were used in the armaments industry, the direct confrontation showed a large technological gap. Modern computer science and electronics were faced with the technique of the 60 s and the 70 s. There is even a larger technological gap in industry and everyday life." [3.14]

There is very limited entrepreneurial tradition in Polish manufacturing. The Polish Government is following the German model of support for small business in anticipation that small- and medium-sized enterprises (SME) will provide the necessary growth. In starting from essentially nothing, there is hope that advanced methods will be implemented by SME to form "islands of technical progress". In this area, the Polish 
recognition of the importance of close contacts with foreign industry for technology diffusion cannot be over emphasized. However, value-added production takes more than just technology: "(Polish) people have to get to the real business of borrowing money and investing it. They've got to start managing people, and the flaws are going to be amplified as they get into long-term production." [3.15]

Size of Enterprises: In 1993, most industrial employment (57\%) was by large companies. Only $\sim 35 \%$ of production was accomplished by private enterprises. [3.16] Statistics suggest that the number of industrial enterprises owned by individuals has declined significantly in 1993 and 1994. A standard support of SME, subcontracting by large companies, is essentially non-existent. This has been suggested as contributing to the recent demise of Polish SME. [3.17] The truth is that the current Polish regulatory and tax infrastructure is unfavorable to their operation. [3.15]

\subsubsection{Economic Factors}

Polish industries are facing economic crises, including a decline in demand for their products and strong global competition even in the controlled domestic market. The economic crises is exacerbated by technology lag and low energy efficiency in production. Combined with a persistent recession and lack of capital, application of advanced manufacturing technologies is rare. Manufacturing companies in Poland are dependent on foreign direct investment (FDI) for application of new technologies.

Status: The unemployment level in Poland has been hovering around $16 \%$. Labor costs have been increasing towards the lower end of the European Union (E.U). pay scale. At these costs, the typically inefficient Polish industry cannot compete with Asian exports, except in a protected market. The E.U. is providing this market to Poland. The Newly Independent States (NIS) also provide a market for Polish goods which can be bartered for gas, rather than currency. [3.18] Although the trade and production statistics may look healthy on paper, it appears that some of the traded goods had no value-added in Poland, and "production" does not mean sales. The booming statistic of Polish entrepreneurs often refers to so-called "suitcase entrepreneurs" who bring suitcases of goods over a border for retail. Value-added activities (i.e., manufacturing), which add wealth to the society, are limited by a resource famine.

Foreign Direct Investment: Manufacturing companies in Poland are dependent on FDI for application of new technologies. Even so, the application of advanced manufacturing technologies by foreign investors is rare. In special circumstances, the World Bank and the E.U. are providing loans for industrial upgrading. Typically, however, there are 
few resources for the introduction of innovations. Polish industry simply cannot afford to conduct or support R\&D. It follows that Polish companies are not developing new products.

With many low-labor-cost countries vying for FDI, the Polish Government has a serious problem demonstrating a stable set of rules and institutions in which multinational companies can plan to operate. Changing protectionist legislation and corrupt bureaucracy are deterrents to FDI. [3.19] The low investment by German enterprises demonstrates the hesitancy towards long-term investment in Poland. The FDI trend in Poland is from Asian companies interested in shortterm investment in order to access the E.U. market without tariffs. It is unlikely that these companies will infuse their Polish operations with advanced technologies. Foreign investment in Poland between 1990 and March 1994 is estimated at $\$ 1.1$ billion in long-term and $\$ 250$ million in short-term investments. It is reported that three quarters of that investment was typically in food products and household articles, not in high-tech products or products requiring high-tech manufacturing capabilities. [3.20]

\subsubsection{Awareness of Emerging Technology}

An explosion of global communications regarding technology is occurring, especially within Europe. In Poland, these communications are bolstered by expanding personnel exchange and technical consulting services from Europe. However, Poland is faced with a very real gulf between awareness and application of emerging manufacturing technologies.

Communications: Polish engineers and scientists can readily access information on state-of-the-art manufacturing for essentially no cost. Communication opportunities are being utilized with foreign experts who study advanced manufacturing technologies for high productivity, quality, and energy efficiency. The E.U. has provided aid through the TEMPUS program for computer connections to Ethernet and to various educational programs. [3.21] Computer connections are considered by Polish scientists to be the most important (and cost effective!) method for "keeping up with world science." [3.22]

Experts: TEMPUS also provides financial aid to encourage Polish educators to visit other European universities. This program is specifically designed to help Poland "to catch up with education in developed countries." [3.21] University curriculum and training programs are transferred during these visits. The E.U. funding has been small but essential.

Consultants are being widely employed in Polish industry, particularly in financial, legal, and marketing areas. Foreign investors are the biggest 
employers of consultants and consulting is a growth business. Foreign aid has recently been used to fund consulting firms to develop technical information. [3.16] Perhaps the most pressing manufacturing issues which consultants are addressing are product quality and productivity improvements.

Training: Polish companies will continue to need to import technology and license proprietary technology with little technical assistance from Polish universities. There are no significant university reforms being enacted at this time. In 1992, university funds were $0.7 \%$ of the GNP, in contrast to $2 \%$ of the GNP of "developed" countries. [3.21] The investment in R\&D at universities is very weak, a real loss of experience for students. However, the importance of technology in the success of the major world powers is taken seriously. The legacy of Poland's controlled market economy is that "the stimulus to improve products and to introduce technical progress does not exist." [3.14] Although this legacy is slowly changing, it is not surprising that the educational system. likewise does not promote technical progress. As rapidly as Poland's markets open to free trade, the educational system will respond under demand to emphasize training needed by industry, rather than mathematics and physics for the sake of those sciences alone.

\subsubsection{Government Efforts}

The main concern of the Polish Government with regards to industrial policy is boosting industry to a level which would allow integration with the E.U. The production statistics must look good very quickly.

Goals: To make Polish industry look healthy, the Government is emphasizing export and production increases. Part of the government effort is to shift defense production to dual use, consumer products. The Government is continuing to subvert free-market principles to boost industry. There is still significant central control of the economy. It has been suggested that this "meddling" is actually slowing industrial growth. [3.16] Many of the market protections in use are common to other European countries. In 1993, the industrial and agricultural production rose again to the 1990 level, but was still only $85.1 \%$ of the production level of 1985. [3.16] Only 55\% of the 1994 GDP was private sector output. [3.24]

Policy: Tariffs on imports to Poland depend on the origination country. The special tariff-free status enjoyed by Poland in trading with Europe is extremely important to the Polish economy. Tariff laws continue to change as special interests are identified. Today raw materials unavailable in Poland are exempt from duties, while those produced in Poland are protected. Imported semi-finished products receive a higher 
tariff, and tariffs are higher still on finished goods. [3.16] The "suitcase entrepreneurs" are finding it lucrative to skirt these tariffs. Private SME bare the brunt of the taxation which is estimated at a $40 \%$ tax on profits, a $22 \%$ value-added tax, and high employment taxes. [3.15] Subsidies and tax breaks are used to prop up certain industries, i.e., SOE ${ }^{6}$. The problem is that the subsidies and tax breaks given to the SOE are typically used simply to keep the industries in operation, not to modernize technology or improve productivity. The SOE are of notoriously low productivity, possibly the main reason the Government is allowing privatization to occur.

Privatization is a very political process: most manufacturing companies which were SOE are still SOE, and the remaining SOE are the largest companies. A recent report pointed out that as of 1990, 2500 of $8400 \mathrm{SOE}$ had been liquidated or privatized. By 1994, this number had risen to approximately 3100 . Most of the privatizing occurs by selling or leasing the assets to the employees. Only $\sim 200$ companies have been sold to investors or though the stockmarket. [3.24] A serious problem for privatization is the strong labor union resistance to MNE (multinational enterprise) buy-outs without guaranteed employment. Although the MNE stand to infuse the companies with much needed capital and technology, these opportunities are sometimes lost.

National RED Plans: The Polish Government has not been seriously involved in foreign technology acquisition and diffusion for economic competitiveness. The Government is the source of almost all R\&D funding. The Committee for Scientific Research (the KNI or the KBN) is the central administration for R\&D financing. Since 1991, the KBN has been distributing resources to the Polish Academy of Science Institutes, the VUZes, and others based on merit. At a total 1995 budget level of 14.37 trillion old zlotys ( $\sim 400$ million) very little manufacturing technology R\&D is to be expected. However, some large investment projects, such as the MAN and NASK networks for computer communications, are a well-used improvement to technical interactions with other countries. It is realized that "there is no way toward economic growth and the conquest of a niche in the future markets of the world other than through sensible investment in scientific R\&D of technology"; yet "the KBN does not manage scientific establishments and does not take administrative measures, it merely administers funding." [3.22] With strong influence from the European Union, it is likely that the KBN will increasingly fund projects with projected industrial potential and the R\&D community will be able to respond. Technology transfer of developments to industry by the Polish R\&D community, however, is viewed as a minimal contribution.

6 SOE is an acronym for both state owned enterprises and state treasury owned companies. 
The following recent $\mathrm{KBN}$ policy statement demonstrates the pervasive credence given to government manipulation of the economy: "The way to economic success leads through a combination of elements of a market economy with those of state intervention, which are expressed through a pro-innovation policy of the state" which should include "adjusting the financial and tax systems and credit policies to the need to support the innovative character of the economy, including the availability of credit on terms that make it possible for investors to get involved in innovative undertakings." [3.23]

\subsection{Taiwan}

Two main mechanisms of manufacturing technology diffusion to Taiwan stand out: technical assistance as a form of FDI by MNE establishing manufacturing facilities or alliances in Taiwan; and government institutes which access and develop available technologies specifically for hightech spin-offs in strategic industries. Taiwanese manufacturing is becoming increasingly dependent on technology diffusion through the Institutes. FDI is going elsewhere in the Pacific and SME are finding traditional low tech manufacturing increasingly nonprofitable. The R\&D sector in Taiwan is judged to be too young to develop advanced manufacturing technologies indigenously without international support, yet have proven their abilities in applying established industrial practices. A narrow manufacturing expertise has emerged in the strategic industries because of this reliance on Institutes and MNE. Industrial policy has been based on technology acquisition and export support, with a commitment to supporting technical education. [3.1] When provided established manufacturing technology, Taiwanese companies are proficient at producing, overseas marketing, and making a profit. This thriving entrepreneurial tradition combined with the Government's past laissez-faire attitude towards SME sets Taiwan apart from Poland and Brazil.

\subsubsection{Technology Level}

In general, the technology level of Taiwanese manufacturing enterprises is slowly increasing in response to competitive pressures. Production in "technology and capital intensive industries" was estimated at $63 \%$ for 1994, compared to $50 \%$ in 1984. [3.25] Although these figures do not identify how much of the gain was due simply to capital investment, there are indications that certain sectors of Taiwanese manufacturing have gained enough experience and resources to begin to use innovative advanced manufacturing technologies. 
Size of Enterprises: Production in Taiwan is carried out by a few large public or private companies active domestically in key sectors or the strategic industries, and a large number of SME which produce goods mainly for export. The concentration of resources in medium- and largesized enterprises is thought to support technology implementation. As the following quote indicates, the dirth of large companies is a concern. "Taiwan's problem is not that it has too many small firms but that there are not enough medium-sized and large units to provide the country's industry with a sufficiently robust structure to meet international competition-especially from Korea and Japan." [3.26]

There is much admiration for the Taiwanese "entrepreneurial spirit" which has been manifested in 750,000 SME in a population close to 21 million. These small businesses are the backbone of Taiwanese commerce, producing goods which are exported through a network of Taiwanese trading firms or MNE. No economies of scale have been required to make these enterprises competitive. Unlike the small Hong Kong enterprises, Taiwanese SME are not typically subcontractors to larger domestic companies. The Taiwanese Government perceives that the SME need to shift towards higher value-added and more researchintensive activities due to increasing competition by low investment, labor intensive manufacturing elsewhere in the Pacific Rim. The Government has not yet intervened in their initiatives beyond domestic market protection and trade promotion. Even technical assistance to SME has been essentially negligible except in some strategic industries. Only in these activities can investment in advanced technology be expected. Some Taiwanese firms, notably Acer (formerly known as Multitech), have been able to make that transition. [3.27] Acer, involved in international alliances and identified with a Government-sanctioned strategic industry, has acquired significant technology from elsewhere.

Globalization: In the 1990s, "economic liberalization" by the Taiwanese Government is designed to promote international investment in large Taiwanese manufacturing enterprises. This policy's success was demonstrated by a recent survey which indicated that of enterprises with more than 300 employees, $44.4 \%$ have foreign funding. Furthermore, foreign funding accounts for over $50 \%$ of capital in $24.4 \%$ of large enterprises. Over $30 \%$ of the strategic computer and electronics industries have received foreign investment.

\subsubsection{Economic Factors}

Taiwanese industries will continue to require diffusion of advanced manufacturing technologies to produce high quality, high-tech products. The Taiwanese economy depends on the export and trade of manufactured goods. The economic changes in the Pacific Rim are enhancing the service orientation in Taiwan as labor intensive 
manufacturing is being displaced. The jump to a sophisticated, indigenous technology base has not yet occurred.

Foreign direct investment in Taiwan has been declining. FDI continues to be a major factor in the prosperity of Taiwanese manufacturing, as a source of capital and an important source of technology diffusion. Electronics, computer, and communications products sectors have been heavily supported by FDI from the U.S. and Japan since the early 1980s when it was first authorized (albeit with FDI limits or "caps"). These products provided a fourth of Taiwan's total export income in 1991, reaching $\$ 18.8$ billion. Recognizing the dual importance of FDI, the Taiwanese Government has recently increased the FDI cap, permitted privatizations, and loosened stock market constraints. Import tariffs for capital goods and raw materials have been drastically reduced from previous levels. The Ministry for Economic Affairs began promoting economic alliances with MNE in February 1993. [3.28]

The problem, however, is that Taiwanese labor costs have risen faster than productivity gains in manufacturing, and some Taiwanese goods are being priced out of the market. "For years the country drew on its cheap labor to offer low manufacturing costs to foreign companies, and did little innovation, introducing textiles, footwear, toys, umbrellas, and other simple products. But, as has happened in all the Asian tigers, labor costs crept upward with prosperity. . . The steady appreciation of the NT\$ since 1985-88 has squeezed the profit margins of SME in the export markets, prompting them to relocate a growing share of their production overseas and/or envisage the establishment of companies in legal forms based on share capital rather than on family funds alone." [3.29]

Taiwanese entrepreneurs, experienced in dealing with foreign markets and transportation of goods are expanding or relocating manufacturing to areas with lower labor costs, recently concentrating on southern China and Vietnam. In essence, companies headquartered in Taiwan are now providing FDI to other countries. Taiwan is reported to have an aggregate investment in Vietnam totaling $\$ 1.9$ billion. It is suggested that the relocated manufacturing involves mostly "intermediate goods or semi-finished products" which are finished in Taiwan and then exported. [3.28] It follows that the available production statistics can be misleading if only the value of goods exported from Taiwan is considered.

\subsubsection{Awareness of Emerging Technology}

The gross dichotomy in technology awareness and acquisition between favored high-tech companies and those in more conventional industries is slowly diminishing. Improving communications infrastructure, rising educational levels, and competitive pressures are combining to encourage technology awareness. 
Competitive pressures (from South Korea, Hong Kong, mainland China, and Singapore, in particular) are forcing more Taiwanese companies to invest in advanced manufacturing technologies to improve productivity. Access to global information and travel has greatly increased. But by far the most significant impact on technology awareness is the dramatic improvement in the education levels and experience with emerging technologies of the engineers and scientists now working in Taiwan. Both provide diffusion of technology via personnel.

Taiwanese companies have benefited from the return of many nationals who have gained experience in U.S. high-tech companies. Since the early 1980s, the Taiwan Government has targeted this group of immigrants to encourage their return. Finally, in the early 1990s, with corporate downsizing in the U.S. and significant public subsidies to locate at the new industrial parks, the Government has achieved its goal. The opportunity to set up their own companies in these incubators has spawned many new businesses and greatly enhanced the caliber of Taiwanese engineers and managers. Often these scientists and engineers received advanced degrees in the U.S. and then worked in Silicon Valley. It is estimated that between 1990 and 1994, 20,000 foreign-educated Taiwanese returned. [3.30]

In proportion to its population, there are more Taiwanese students in U.S. graduate schools than students from any other country. [3.30] The caliber of education and exposure to technology in foreign universities will continue to draw these students and support Taiwanese manufacturing. [3.31] With improving domestic prosperity, the numbers of Taiwanese attending universities in Taiwan is increasing. In 1990, $5.88 \%$ of the GNP was spent on all forms of education (up from $3.38 \%$ GNP in 1965). [3.32] This percentage is now higher than most OECD countries. The Ministry of Education emphasizes science and engineering programs. In 1990, 9000 engineering degrees and 5000 computer science and mathematics degrees were conferred. This represents a two-fold increase since 1982. [3.32] Graduate programs also emphasize technical disciplines. There is firm public support of education and a perception that advanced education in the technical fields will allow the country to meet high-tech challenges. There are similarities in the Taiwanese emphasis on education with that of Japan in the 1970s.

\subsubsection{Government Efforts}

The Taiwanese government currently sponsors the acquisition, development, and internal diffusion of foreign technology into a few

7 OECD is the Organization for Economic Cooperation and Development to which most European Countries, Japan, Australia, Canada, and the U.S. belong. 
favored industrial sectors. These industries (e.g., computers) have been identified as strategic industries for Taiwan. Because it is viewed domestically as successful, this policy of sponsorship is expected to continue over the next decade, although public funding will not increase as rapidly as in the 1980 s.

Goals: The most important economic goal of the Taiwanese government is to dominate inter-Pacific trade as a financial clearing house and entrepot port. ${ }^{8}$ The government is clearly supporting infrastructure development for transportation networks ahead of all other projects. As the world's fourteenth largest trader with foreign-exchange reserves of more than $\$ 80$ billion, the Taiwanese government is maneuvering for membership in the World Trade Organization, and eventually, the United Nations. [3.33] Taking second place to this goal is continuing support of indigenous industrial development. Although some Taiwanese wish their nation to become a center for high-tech $R \& D$, government support for these activities falls short of that needed to boost innovation capabilities to rival Japanese, German, or U.S. efforts. With wage increases surpassing productivity increases, domestic manufacturing is becoming less profitable then in the past. It is likely that trade and finance will continue to be viewed through the 1990s as areas with higher return than advanced manufacturing.

National RED: A popular Taiwanese industrial strategy has been to "cash in on the large follow-up market for already established products." [3.34] The Taiwanese excelled at producing "established products" at less cost than companies in countries where the basic product design was first developed. Truly an effort in technology diffusion, the Taiwanese adopted the Japanese model, lagging Japan by about ten years. There continues to be a strong reliance on the import of technology, both in product concepts and in manufacturing capabilities.

In the 1970s, Taiwan's Government began encouraging domestic technology development. In the 1980s, the trend was furthered to encourage manufacturing companies to pursue high-tech, strategic industries. Foreign investment was critical to establishing manufacturing capabilities in heavy industries. However, government involvement was also deemed necessary because the pervasive small companies would not pursue R\&D for high-tech products. [3.35] Government institutes (e.g., ITRI) were then set up as high-tech industrial incubators. These incubators have spawned industrial parks and are considered successful by the Taiwanese Government.

Research, technology transfer, and product development are conducted in government establishments, most notably institutes and more recently, universities. The institutes are primarily responsible for acquiring and assimilating technologies which might not be transferred

\footnotetext{
${ }^{8}$ An entrepot port is defined as an intermediary center of trade and transshipment.
} 
to Taiwan by MNE. Development projects are identified for a few major strategic industries and carried out in these institutes. The projects are . designated in 4-year plans. In 1982, the eight priority research areas were materials science, information technology, automation, genetic engineering, energy, lasers, hepatitis prevention and therapy, and food processing. [3.36] The current research areas include electronics, information technology, aerospace, environmental technologies, medical and pharmaceuticals, and precision machinery (including automation). In the 1990s, the Taiwanese Science Council is overseeing an increase in basic engineering research at universities. Although this is an effort to develop advanced manufacturing technologies, it is currently an academic pursuit disconnected from industry. Research areas are chosen based on the research agendas of the U.S. National Science Foundation and the Japan Science and Technology Agency, as well as current topics at international conferences. The tendency towards theoretical research topics, without concurrent research in practical applications, will diminish the value of this investment. The four strategic engineering areas identified in 1994 are automation engineering, medical-controlelectrical engineering, microwaves-communications-signal processing, and metals-ceramics. The funding level for these efforts approaches NT\$400 million (\$15 million) per year. [3.37]

Spending on R\&D increased dramatically in the 1980s, concurrent with increases in the salaries of researchers and the numbers of high-tech start-ups wooed by government subsidies. It is reported that "in 1993, high-tech factories spent $\$ 1.69$ billion for R\&D, up $23.7 \%$ from 1991. " In comparison, the single largest U.S. industrial R\&D supporter, General Motors, spent $\$ 5.92$ billion on R\&D in 1992. The total Taiwanese R\&D investment in 1990 reached $\$ 2.5$ billion. [3.35] Other information also suggests that the actual expenditure on $R \& D$ is low. Taiwan currently invests $~ 1.73 \%$ of its GDP on R\&D (1.2\% of GNP in 1988), lower than the international norm of $2 \%$. These figures probably include the extensive costs of subsidies to promote selected high-tech companies, which is a major tool of Taiwanese industrial policy.

Policy: The Taiwanese government sponsors strategic industries by several methods to initiate technical development. In order to concentrate resources, the focus is currently on industrial parks. These parks (i.e., business incubators) have been planned in conjunction with government institutes to facilitate tech transfer and spin-offs. Three main incentives are used to promote high-tech business development in the parks. The most obvious is the proximity to the institutes which includes access to R\&D, services, and potential consortium memberships. Second, special financial incentives are available including reduced rents, loans, and preferential tax incentives. The institutes are now associated with venture capital companies, which further support institute spin-off technologies. Third, the upscale living facilities and educational opportunities make the industrial parks desirable residence areas. The 
amenities are planned to encourage scientists and engineers who are living abroad to return to Taiwan and work in the parks.

For several decades the Taiwanese Government implemented very strong domestic market protection to promote indigenous industry. This protection is being slowly reduced for three main reasons: Taiwan desires entrance into the World Trade Organization; foreign direct investment (FDI) in Taiwan is dropping; and, as other Asian countries become more global, Taiwanese companies are facing increasing competition. Reduced domestic market protection is expected to indirectly encourage technology diffusion.

\section{Examination of One Industry: Automobiles}

The examination of the automobile industry in Brazil, Poland, and Taiwan indicates that Multinational Enterprises (MNE) ${ }^{9}$ are the most important technology diffusion mechanism. We find that international standards and benchmarking drive the need for technology improvements in both product design and in manufacturing. The automobile industry depends on other industries as well (e.g., raw material suppliers, machine tool manufacturers, etc.). Because of increasing quality and performance requirements, the demand for and access to technology in the automobile industry is recognized as playing a major role in the development of a country's industrial infrastructure. All three countries are experiencing growth in this industry (see Table 4.1).

\subsection{Predominant Technology Diffusion Mechanism}

Multinational enterprises (MNE) are the most important technology diffusion mechanism for the automobile industry in all three countries.

\subsubsection{Brazil}

Many automobile and component producers operating in Brazil are wholly or majority-owned foreign affiliates of MNE (see Table 4.2). Consequently, most of the technology used is transferred by the parent company. A few companies have recently established small R\&D centers to investigate developments particular to the Brazilian market (e.g.,

${ }^{9}$ As defined in Section 2, technology diffusion via MNEs includes joint ventures, consortia, product development alliances, and transnational coalitions/mergers. 
Table 4.1. Automobile Manufacturing. [4.1-4.4]

\section{Vehicles}

\begin{tabular}{|c|c|c|c|c|c|}
\hline Country & Year & $\begin{array}{l}\text { New Registrations } \\
\text { (thousand units) }\end{array}$ & $\begin{array}{l}\text { Local Production } \\
\text { (thousand units) }\end{array}$ & Exports & Imports \\
\hline \multirow[t]{2}{*}{ Brazil } & 1993 & 770 & 960 & $\begin{array}{c}200 \\
(20 \%)\end{array}$ & $\begin{array}{c}5 \\
(<1 \%)\end{array}$ \\
\hline & 1994 & 1,140 & $\begin{array}{c}1,391 \\
(12,000 \mathrm{M})\end{array}$ & $\begin{array}{c}331 \\
(\$ 2,913 \mathrm{M})\end{array}$ & 80 \\
\hline \multirow[t]{2}{*}{ Polland } & 1991 & 210 & 180 & $\begin{array}{c}40 \\
(22 \%)\end{array}$ & $\begin{array}{l}20^{* *} \\
(12 \%)\end{array}$ \\
\hline & $\begin{array}{c}\text { Average } \\
(1991-1995)\end{array}$ & 1,100 & 500 & & \\
\hline \multirow[t]{2}{*}{ Taiwan } & 1991 & 550 & 210 & $\begin{array}{c}<2 \\
(<1 \%)\end{array}$ & $\begin{array}{c}60 \\
(30 \%)\end{array}$ \\
\hline & $\begin{array}{c}\text { Average } \\
(1991-1995)\end{array}$ & 3,200 & 1,500 & & \\
\hline
\end{tabular}

Components: Automotive Parts and Service Equipment

\begin{tabular}{lccccc}
\hline Country & Year & $\begin{array}{c}\text { Component Sales } \\
(\text { Million } \$)\end{array}$ & $\begin{array}{c}\text { Local Production } \\
\text { (Million } \$)\end{array}$ & $\begin{array}{c}\text { Exports } \\
\text { (\% production) }\end{array}$ & $\begin{array}{c}\text { Imports } \\
\text { (\% sales) }\end{array}$ \\
\hline Brazil & 1993 & 11,250 & 12,500 & 2,250 & $\begin{array}{c}1,000 \\
(9 \%)\end{array}$ \\
& $1994^{*}$ & 12,120 & 13,500 & 2,430 & 1,1050 \\
\hline Poland & 1993 & 535 & 368 & 46 & 213 \\
& $1994^{*}$ & & & $(12 \%)$ & $(40 \%)$ \\
& 1993 & 580 & 390 & 50 & 240 \\
\hline Taiwan & 4,200 & 4,000 & 1,000 & 1,200 \\
& $1994^{*}$ & 4,500 & & $(26 \%)$ & $(28 \%)$ \\
& & & 4,300 & 1,200 & 1,400 \\
\hline
\end{tabular}

* Estimated.

** When including individual transaction and used cars, imports reach 350,000 . 
Table 4.2. Brazil, 1993. [4.3]

Vehicle manufacturing/assembly companies

\begin{tabular}{|c|c|c|c|}
\hline Company & Products & 1993 Production & Venture \\
\hline Volkswagen* & Full range & 450,000 & German \\
\hline Fiat & Cars/light commercial & 393,596 & Italian \\
\hline GM & Cars/light commercial/trucks & 274,972 & U.S. \\
\hline Ford* & Full range & 213,000 & U.S. \\
\hline Mercedes-Benz & Trucks/buses & 33,679 & German \\
\hline Scania & Trucks/buses & 6,289 & Swedish \\
\hline Volvo & Trucks/buses & 5,739 & Swedish \\
\hline Toyota & 4WD pickup & 2,627 & Japanese \\
\hline Agrale & Trucks & 1,444 & Brazilian \\
\hline Gurgel & (bankrupt 1993) & 437 & Brazilian \\
\hline
\end{tabular}

\section{Major components manufacturers by products}

\begin{tabular}{llcc}
\hline Company & \multicolumn{1}{c}{ Main Products } & $\begin{array}{c}\text { Total Sales } \\
(\mathrm{M} \$)\end{array}$ & Venture \\
\hline Bosch* & Fuel pumps, injectors, electrical parts & 650 & German \\
\hline Maxion & Engines, heavy wheels, chassis & 421 & Brazilian \\
\hline Cofap & Shock absorbers, cylinder liners & 378 & Brazilian \\
\hline Metal Leve & Pistons, piston rings, cylinder liners & 251 & Brazilian \\
\hline ZF & Gearboxes, power steering, pumps & 195 & German \\
\hline TRW & Engine valves, steering systems & 170 & U.S. \\
\hline Clark & Gearboxes & 160 & U.S. \\
\hline MWM & Diesel engines & 156 & German \\
\hline Varga & Brakes, brake systems & 151 & Brazilian \\
\hline Wapsa & Electronic components & 150 & German \\
\hline Allied Signal & Turbo systems, filters, horns & 119 & U.S. \\
\hline Albarus & Driveshafts, hydraulic controls & 118 & U.S. \\
\hline Cummins & Diesel engines & 118 & U.S. \\
\hline ATH & Universal joints & 113 & U.S. \\
\hline Rockwell Braseixos & Axles & 112 & Brazilian \\
\hline Sifco & Forged parts & 109 & Brazilian \\
\hline Microlite & Batteries & 103 & U.S. \\
\hline & & & \\
\hline
\end{tabular}


alcohol-fueled cars). The Brazilian Government has no ownership in any of this industry's companies. The domestic market is by far the most important, followed by export to other South American countries. [4.3] Automotive parts are a very large part of the industry, surpassing vehicle assembly in production value for 1992 (see Table 4.2). A dramatic range in modernization exists from operations having no automation to Fiat's Betim complex "arguably the most modern car plant in Brazil... (where) automation is still low by international standards". [4.2]

\subsubsection{Poland}

A major industry transformation is occurring as Polish automobile producers form joint ventures with MNE to access advanced technology, capital equipment, and best manufacturing practices. By $1992,85 \%$ of vehicle assembly in Poland involved a foreign company (see Table 4.3). [4.5] This percentage is increasing as the investment of multinational companies is welcomed. Prior to the opening of Poland's market little investment in modernization had been made, and productivity was predictably low. The recent exposure of state-owned producers to limited foreign competition has caused severe financial hardships. With the plethora of MNE improvements and know-how, exports are positioned to grow. The Polish component manufacturers will see significant gains over the next several years as many of the assembly ventures are required to phase-in domestic components. Much of the technology presently used to manufacture components was licensed from MNE (see Table 4.3).

\subsubsection{Taiwan}

Taiwanese automobile and component manufacturers are rapidly increasing ties to MNE. Industrial policy has traditionally restricted foreign equity holdings in Taiwan to minority shares. Consequently, the Taiwanese automobile assembly and components companies typically license technology from $\mathrm{MNE}$ with minority equity in their company. [4.1] Three main factors are motivating closer ties with MNE. Access to technology is considered the most significant. The Taiwan industry has been recognized as supplying low-end auto parts for after-sale markets. [4.4] The larger companies now seek to break into the high-end market. Second, "liberalization" of industrial policies are increasing imports with which the previously protected Taiwanese automobile assemblers currently cannot compete. Most are suffering losses. Joint ventures with MNE are sought to provide new capital for modernization to raise productivity. Third, several Taiwanese component manufacturers plan to set up facilities in China. Partnership with a Japanese or U.S. firm provides some protection guarantees by the Chinese Government. [4.6] 
Table 4.3. Poland, 1992. [4.5]

Vehicle manufacturing/assembly companies

\begin{tabular}{lccl}
\hline \multicolumn{1}{c}{ Company } & Products & 1992 Production & \multicolumn{1}{c}{ Venture } \\
\hline FSO & Cars & 72,547 & $\begin{array}{l}\text { New venture w/GM to update } \\
\text { production }\end{array}$ \\
\hline $\begin{array}{l}\text { (Fiat Auto Poland) } \\
\text { FAP }\end{array}$ & Cars & 70,083 & $\begin{array}{l}\text { New venture 51\% Fiat/49\% } \\
\text { SOE* w/ priv. planned }\end{array}$ \\
\hline FSC/ Zuk & Trucks & 10,040 & Peugeot assembly, SOE* \\
\hline $\begin{array}{l}\text { (Renault Trucks Polska) } \\
\text { FSC/ Star }\end{array}$ & Trucks & 1,610 & 1995 starting Renault assembly \\
\hline FSD/Nysa & Trucks & 5,400 & SPE \\
\hline JZS/Jelcz & Trucks/buses & 2,550 & Venture with Volvo \\
\hline FSA/ Autosan & Buses & 720 & $\begin{array}{l}\text { SOE*, } \\
\text { Mercedes engines }\end{array}$ \\
\hline SHL/Kielce & Trucks & 480 & \\
\hline FSR/ Tarpan & Trucks & 450 & $\begin{array}{l}\text { Expanding, New Volkswagen } \\
\text { venture }\end{array}$ \\
\hline Karpena & Trucks & (starting 1993) & Assembly for Scania \\
\hline
\end{tabular}

\section{Major component manufacturers by products}

\begin{tabular}{lll}
\hline \multicolumn{1}{c}{ Company } & \multicolumn{1}{c}{ Products } & Venture \\
\hline FSC & $\begin{array}{l}\text { Shock absorbers, engine housings } \\
\text { Suspensions, rear axles, wheels }\end{array}$ & $60 \%$ Daewoo \\
\hline Zelmot & Ignition systems & Recently privatized? \\
\hline Cegielski & Small engines & Under Sulzer license \\
\hline Stomil & Tires & Tech. license from Continental in 1991 \\
\hline Exbud & Fiber glass materials & $\begin{array}{l}\text { Tech. venture by Polyester } \\
\text { Polyurethane Technik, Germany }\end{array}$ \\
\hline $\begin{array}{l}\text { Volkswagen } \\
\text { Elecktro-Systemy }\end{array}$ & Electrical systems & $\begin{array}{l}\text { New venture by Volkswagen \& } \\
\text { Siemens }\end{array}$ \\
\hline Automotive \\
Equipment Works & Carburetors & \\
\hline Motorization & Seatbelts & \\
Enterprize & Wiring harnesses, lights & FSO subsidiary w/ GM venture \\
\hline ZEM-ELK & Isolation materials & Ford investment \\
\hline Polovat & Seat covers & \\
\hline Autodecor & &
\end{tabular}

${ }^{*}$ (SOE is an acronym for both State-Owned Enterprises and State Treasury-Owned Companies.) 
Table 4.4. Taiwan, 1994. [4.8]

Vehicle manufacturing /assembly companies.

\begin{tabular}{lcl}
\hline \multicolumn{1}{c}{ Company } & 1994 Production & \multicolumn{1}{c}{ Venture } \\
\hline China Motor Co & 113,375 & $\begin{array}{l}\text { Joint venture, } \\
\text { Owned 19\% by Mitsubishi }\end{array}$ \\
\hline Ford Lio Ho Motor & 97,706 & $\begin{array}{l}\text { Owned 70\% by Ford } \\
\text { oint venture w/ Mazda and Kia }\end{array}$ \\
\hline Yulon Motor Co & 62,602 & Partner w/ Nissan \\
\hline Yue Loong Motor Co & 55,891 & $\begin{array}{l}\text { Owned 25\% by Nissan, } \\
\text { Tech. joint venture }\end{array}$ \\
\hline San Yang Industry Co & 51,408 & \begin{tabular}{l} 
Joint venture with Honda \\
\hline Kuozui
\end{tabular} \\
\hline 50,000 & $\begin{array}{l}\text { Owned 49\% by Toyota, } \\
\text { Tech. joint venture }\end{array}$ \\
\hline Sanfu Motors Industry & $* 20,000$ & $\begin{array}{l}\text { Renault assembly, } \\
\text { (1995 alliance w/ Izuzu and Itochu) }\end{array}$ \\
\hline Yue Tien Machinery Co & 14,601 & $\begin{array}{l}\text { Owned } 40 \% \text { by Hutton, } \\
\text { Tech. from Peugeot \& Daihatsu }\end{array}$ \\
\hline Prince Motors Co & 7,612 & Tech. License w/ Suzuki \\
\hline
\end{tabular}

Major component manufacturers by products.

\begin{tabular}{lll}
\hline \multicolumn{1}{c}{ Company } & \multicolumn{1}{c}{ Products } & \multicolumn{1}{c}{ Venture } \\
\hline Chinese Automőbile Co & & GM AC Delco \\
\hline Kasai Kogyo Co & Car interiors & Nissan \\
\hline ROC Spicer (Yulon) & Axles, driveshafts, CV joints & Dana Corporation \\
\hline Uni Calsonic & Radiators, mufflers & Owned 50\% by Calsonic \\
\hline Ford Lio Ho Motor & Injection systems, airbags & Ford \\
& Catalytic converters & \\
\hline Ensure & Cast iron castings & Izuzu? \\
\hline \multicolumn{1}{c}{$?$} & Hub and diff locks, oil pumps & Tochigi Fuji Industrial Co (Nissan) \\
\hline Atsugi & Oil pumps & Joint venture, \\
& Power steering pumps & Owned 45\% by Unisia \\
\hline ITRI (spin-off) & Auto engines (1997) & $\begin{array}{l}\text { Hutton engine design venture } \\
\text { (Lotus, Rover?) }\end{array}$ \\
\hline
\end{tabular}

* Approximate production. 


\subsection{Technology Driver}

International standards for quality and performance require technology improvements, both in product design and in manufacturing. These technology improvements are continual for automobiles, which is often considered the world's most competitive industry. Global benchmarking is driving the need for technology in Low Average Productivity (LAP) countries.

Outsourcing (subcontracting) for components is now common for assembly operations. If components manufacturers wish to export to assembly operations around the world, they must meet benchmarking requirements. Because most improvements (upgrades) are made in components, the assembly operations rely on their component suppliers to implement new technologies. Subcontracting encourages smaller manufacturers to assimilate technology and "the most pervasive form of technological know-how absorption through subcontracting is the mastering of quality assurance and other forms of 'good manufacturing practice'. The resulting stringent quality and delivery performance requirements of these MNE procurement activities have thus exposed local SME subcontractors to internationally competitive market environments." [4.9] To access equipment, subcomponents (e.g., semiconductors), and new technologies, both assembly operations and component manufacturers must be connected to external markets. These manufacturers can no longer afford to be isolated. Research also indicates that "the involvement of foreign firms... seems to be necessary if constant improvements in cost and quality are to be made. . . Neither in components nor assembly do the selected (LAP) countries possess technology of their own, even if considerable learning by doing has taken place." [4.1]

Although it is recognized that international cooperation is necessary for export in the automobile industry, there are concerns in LAP countries that the industry, built on technology controlled by MNE, is dependent and vulnerable. The suggestion is that most technology which diffuses through MNE is old. However, by installing tried and proven technology, MNE avoid risks. As one study demonstrated "the analysis of the pooled data suggested a fairly marked negative relationship between the speed of diffusion and the time lag in introduction: in countries which are pioneers, diffusion tends to be slower. This result is consistent with the hypothesis that the pioneer faces all sorts of teething troubles- new problems associated with the new technique- which are likely to be solved, partly and gradually, by the time others adopt it. It is therefore not necessarily desirable to be the first to introduce a new technique." [4.10] 


\subsection{Automobile Industry Progression}

Technology diffusion in the automobile industry can play a dominant role in a country's manufacturing development. The so-called "linkage effects" with other industries have been carefully studied. [4.1] A progression from assembly of kits (dominated by turn key facilities and kits from MNE), to component manufacture (as subcontractors or subsidiaries of MNE and utilizing licensed technologies), to a flexible domestic manufacturing infrastructure appears to be natural. This progression requires an increasing ability to absorb technology. "While technology transfer focuses on the technology flow process between two parties, technology absorption refers to the active efforts of the recipient party to invest in the adoption of the technology in the first place, to utilize the technology it received, and to subsequently improve upon it. Absorption of technology by a firm thus typically involves three generic stages: technology search, evaluation and acquisition; technology learning and implementation; and finally, technology adaptation and innovative application." [4.9] In effect, the strategy for technology transfer in joint ventures with MNE is described as "first importing and assembling; second, assimilating foreign technology and rapidly localizing production; third, setting up a dynamic process of transfer of the technology." [4.11] A more generic progression also suggests three steps in technology sophistication: "i. ability to produce well-established products more competitively than other possessors of essentially the same technology; ii. introducing higher-quality products within existing product areas; and iii. a leading position amongst the firms capable of innovating major new product concepts." [4.12] In any of these descriptions, the domestic manufacturing capability is expected to progress as technology becomes increasingly available and utilized.

\section{Trends}

Technology diffusion to all three countries (Brazil, Poland and Taiwan) will increase in importance for manufacturing. Prediction of the rates of technology diffusion to these countries is impossible for one major reason: their governments' industrial policies vacillate. In this section we will attempt to predict some trends which will influence technology diffusion rates. The major trend observed today is a worldwide inclination towards "freer" markets. Even the currently popular regional alliances will promote interactions across national borders. This major trend will encourage faster technology diffusion. Growing national competition to attract foreign investment will guide this trend. 
The attractiveness of a country to foreign investment usually depends on the country's "position" or infrastructure. In this sense, a country's infrastructure includes geographic location with respect to major transportation routes, energy and material resources, availability of low wage labor, and government policy and incentives. Competitiveness rankings for 41 countries were recently compiled by a group of international representatives ${ }^{10}$. [5.1] Brazil, Poland, and Taiwan were ranked 38,41, and 18, respectively. A few of the selected category rankings which contributed to the overall ranking are listed in Table 5.1. Most of the selected category rankings tend to cluster close to the overall ranking. For instance, "internationalization" was ranked at 36, 41, and 17, respectively. The "business risk" ratings compiled for several years by professional economists are presented in Figure 5.1 for several years. [5.2] The 1995 risk ratings for Brazil, Poland, and Taiwan follow a pattern similar to the competitiveness ranking. Brazil was given a business risk rating six times that of Taiwan.

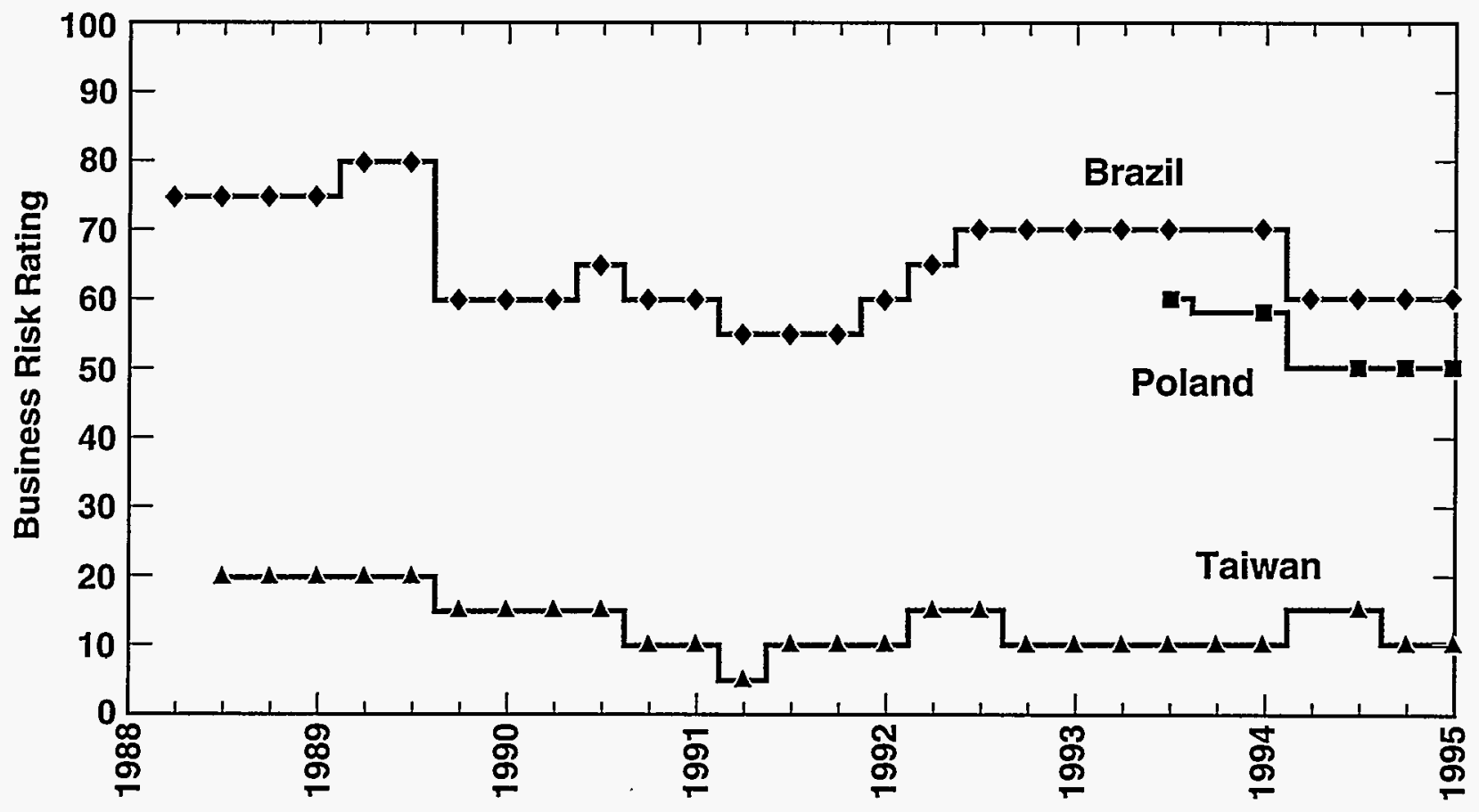

15-H/054-02

Figure 5.1. Business risk rating. [5.2]

10 The U.S. was ranked 1 out of 41 countries. 
Table 5.1. Competitiveness Rankings. [5]1

\begin{tabular}{|lccc|}
\hline & Taiwan & Brazil & Poland \\
\hline Overall Competitiveness Ranking: & 18 & 38 & 41 \\
Selected Category Rankings: & & & \\
Domestic Economic Strength & 5 & 41 & 38 \\
Internationalization & 17 & 6 & 41 \\
Productivity & 21 & 37 & 34 \\
Science and Technology & 15 & 38 & 35 \\
People & 19 & 37 & 32 \\
Government & 11 & 35 & 40 \\
Finance & 20 & 36 & 40 \\
Infrastructure & 27 & 30 & 38 \\
Management & 21 & 35 & 41 \\
\hline
\end{tabular}

\subsection{Brazil}

Despite the mentioned rankings and ratings, we predict that Brazil is positioned for the most rapid technology diffusion and manufacturing growth of the three countries. The pivotal factor will be the Brazilian Government's ability to continue its current trend to reduce protectionist policies and effect a stable legislative environment. Foreign investment in Brazil has greatly exceeded that in Poland or Taiwan (see Figure 5.2). In the last decade, foreign investment in Brazil has overwhelmingly favored stocks (short-term) rather than FDI (long-term) because of the uncertain political climate and restrictive investment rules. Brazil's resources (including population, land, and raw materials) are plentiful (see Table 5.2).

\subsection{Poland}

Technology diffusion into Poland will continue at a slow pace as foreign investment trickles in. The slow pace is expected because Poland's 

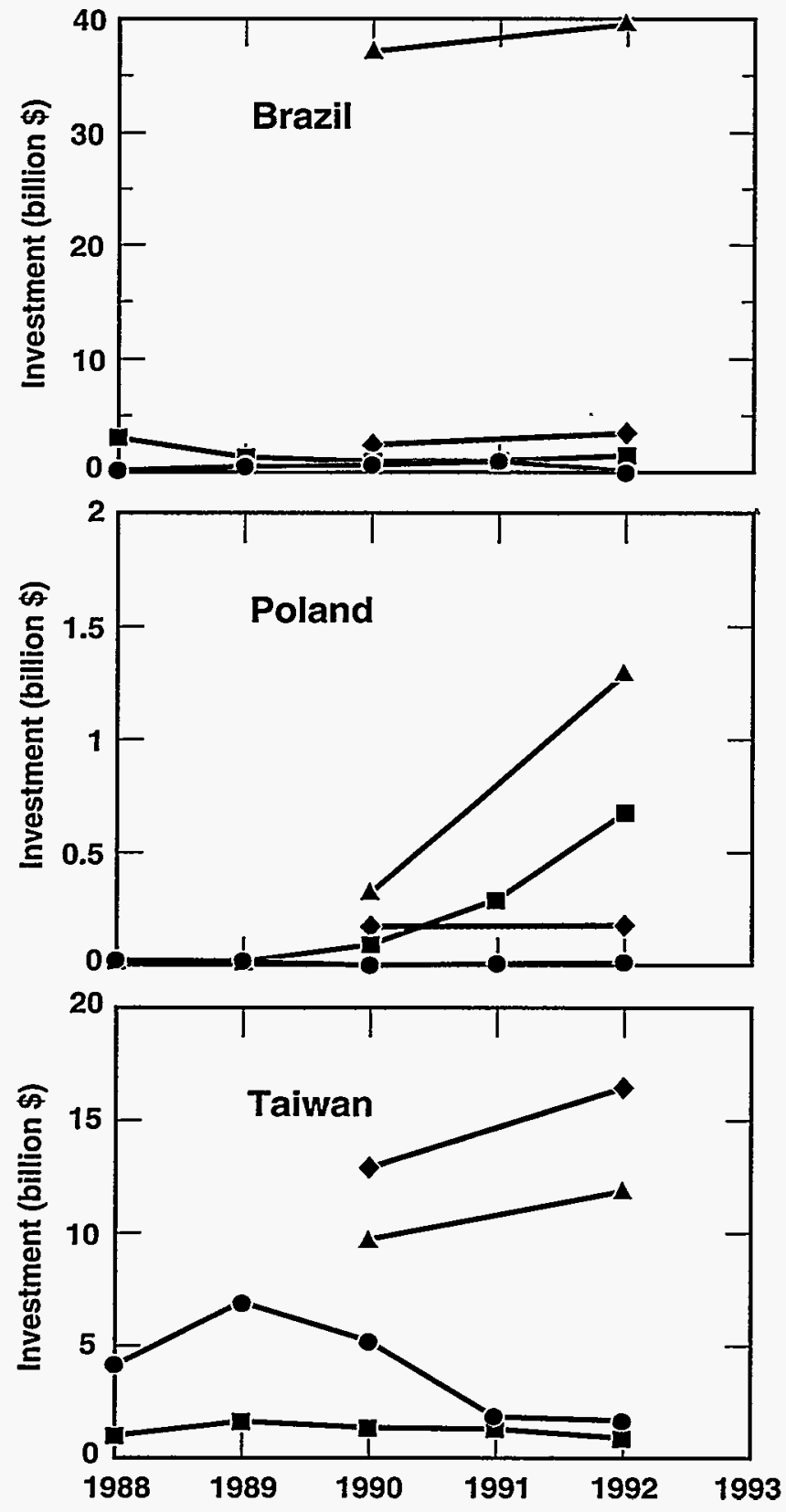

15-H/054-03

Figure 5.2. Investment flowing into and from Brazil, Poland, and Taiwan; 1 FDI in, $\bullet$ FDI out, $\Delta$ Stock in, $\rightarrow$ Stock out. [5.3] 
Table 5.2. Sadistics.

\begin{tabular}{|c|c|c|c|}
\hline & Brazil & Poland & Taiwan \\
\hline Foreign affiliates located in country [5.2] & $\begin{array}{l}8576 \\
(1992)\end{array}$ & $\begin{array}{l}3800 \\
(1992)\end{array}$ & $\begin{array}{l}5733 \\
(1990)\end{array}$ \\
\hline $\begin{array}{l}\text { Number of transnational parent } \\
\text { corporations based in country [5.2] }\end{array}$ & $\begin{array}{l}566 \\
(1992)\end{array}$ & $\begin{array}{l}58 \\
(1992)\end{array}$ & $\mathrm{n} / \mathrm{a}$ \\
\hline $\begin{array}{l}\text { Manufacturing } \\
\text { Production [5.6] }\end{array}$ & $24 \%$ of GDP & $40 \%$ of GDP & $31 \%$ of GDP \\
\hline $\begin{array}{l}\text { Manufacturing } \\
\text { Labor Cost [5.4] }\end{array}$ & $\begin{array}{l}\$ 2.7 / \mathrm{hr} \\
(1993)\end{array}$ & $\begin{array}{l}\$ 1.4 / \mathrm{hr} \\
(1993)\end{array}$ & $\begin{array}{l}\$ 5.0 / \mathrm{hr} \\
(1993)\end{array}$ \\
\hline $\begin{array}{l}\text { Manufacturing Sector [5.5] } \\
\text { (\% of workforce) }\end{array}$ & $\mathrm{n} / \mathrm{a}$ & $(25.4 \%$ in 1988$)$ & $28 \%$ \\
\hline R\&D (\%GDP) & $\begin{array}{l}\sim 0.8 \% \\
(1994)\end{array}$ & $\begin{array}{l}\sim 0.5 \% \\
(1993)\end{array}$ & $\begin{array}{l}1.73 \% \\
(1993)\end{array}$ \\
\hline GDP/capita [5.5] & $\$ 3,007$ & $\$ 2,238$ & $\$ 10,200$ \\
\hline Population [5.5] & $162 \mathrm{M}$ & $38.4 \mathrm{M}$ & $21 \mathrm{M}$ \\
\hline Official Unemployment [5.5] & $9.8 \%$ & $16 \%$ & $1.5 \%$ \\
\hline
\end{tabular}

industrial policy is unlikely to experience a dramatic trend towards a freer market. In the coming decade, Polish manufacturing will probably continue to be "boot strapped" by subsidies and concessions from the E.U.There is a strong movement within the OECD member countries (particularly in Europe) to "harmonize policy" and "develop international rules". [5.6] First in importance are rules for access to and transfer of technology. Secondly, "development of multilateral rules concerning the use of financial and other inducements to attract foreign firms and investment" are being advocated along with "harmonization of national competition policies". An agenda of this sort will further encourage Polish manufacturing to accommodate technology at a slow and controlled rate.

\subsection{Taiwan}

Manufacturing in Taiwan is facing an erosion of investment at home at a time when domestic technology innovation is just beginning to be 
commercialized. The trend towards FDI out of Taiwan to lower wage Asian countries can be observed in Figure 5.2. In general, it appears that the trend among their industries is to stay with low cost, labor intensive manufacturing rather than seeking to increase productivity. Taiwan is facing its own "hollowing-out" before the nation's industries are capable of advanced technology development. The need for advanced technology and related manufacturing equipment is expected to increase as their production capacity expands in Asia and competition increases in the years to come. Taiwanese manufacturing will remain dependent on technology diffusion. 


\section{References}

[1.1] "Science and Technology," The OECD Observer, No. 194, June/ July 1995.

[1.2] OECD SET Indicators Report No. 3: RED, Production and Diffusion of Technology (OECD, Paris, 1989), pp. 30-37.

[1.3] Erik J. de Bruijn and Xianfeng Jia, "Transferring Technology to China by Means of Joint Ventures," Research Tech. Mngt., 17-22 (JanuaryFebruary 1993).

[1.4] Aleta Tesar, Advanced Manufacturing: Technology and International Competitiveness. Lawrence Livermore National Laboratory, NAI Directorate, Livermore, Calif., UCRL-ID-120595 (February 1995).

[1.5] Douglas Ostrom," Trade White Paper highlights 'Hollowing Out'," JEI Report No. 21B, Japan Economic Institute, Washington, D.C., June 9, 1995, p. 6.

[1.6] Dennis Normile, Japan Holds On Tight to Cutting-Edge Technology, Science 262, 352, (October 15, 1993).

[1.7] David P. Hamilton and Steve Glain, "Silicon Duel: Koreans Move to Grab Memory-Chip Market From the Japanese. The Wall Street Journal, A1 (March 14, 1995).

[2.1] Robert Brainard, Globalization and Corporate Nationality. STI Review 13, 163-187 (OECD, Paris, 1993).

[2.2] Leonard M. Fuld, The New Competitor Intelligence (John Wiley \& Sons, NY, 1995).

[2.3] Michael Moynihan and Ronald S. Jonash, "Leveraging Technology in the New Global Company," The Economist Intelligence Unit, Research Report No. I-117, 1993.

[2.4] Syed S. Kirmani and Warren C. Baum, The Consulting Profession in Developing Countries: A Strategy for Development, World Bank Discussion Paper No. 149, The World Bank, Washington, DC, 1992.

[2.5] Marina Papanastassiou and Robert Pearce, "The Internationalization of Research and Development by Japanese Enterprises, R\&D Man. 24 (2), 155-165 (1994).

[2.6] Ashoka Mody, Staying in the Loop: International Alliances for Sharing Technology, World Bank Discussion Paper No. 61, 1989.

[2.7] Francois Chenais, "National Systems of Innovation, Foreign Direct Investment and the Operations of Multinational Enterprises," National Systems of Innovation, ed. Bengt-Ake Lundvall (Pinter Publishers, London: 1992).

[2.8] Wong Poh Kam, Technological development through subcontracting linkages, Asian Productivity Organization, 1991.

[2.9] Jim Northcott and Graham Vickery, "Economic and Structural Conditions Affect Diffusion and Use Differently," STI Review \#12 (OECD, Paris, April 1993). 
[3.0] Raymond Vernon, "A Strategy for International Trade," Issues in Science and Technology, 86-91 (Winter 1988-89).

[3.1] Michael Moynihan and Ronald S. Jonash, "Leveraging Technology in the New Global Company," The Economist Intelligence Unit, Research Report No. I-117 (1993).

[3.2] Joao Carlos Ferraz, Howard Rush, and Ian Miles, The Brazilian Style of Development (Routledge, Chapman, and Hall, Inc., NY, 1992).

[3.3] "Brazil: Funds from Privatization to be Used for Science," Journal Do Brasil, Rio de Janeiro, 8 (June 6, 1994); [94WS0392A translated in JPRSEST-94-022, 14 (August 29, 1994).]

[3.4] Brazil: Causes and Dimensions of the Technological Lag. CPMI (Joint Congressional Investigative Commission), National Congress of the Federal Republic of Brazil: 1991. [translated in JPRS-EST-93-042, December 20, 1993.]

[3.5] DSSCS Message, VZCZCMSS0940, R011830Z, September 1994. [3.6] "Emerging-Market Indicators," The Economist, 136 (November 12, 1994).

[3.7] "Emerging Market Indicators," The Economist, 110 (June 25, 1994). [3.8] Geri Smith and Bill Hinchberger, "Brazil: Is the Recovery For Real?," Business Week, 66-67 (October 3, 1994).

[3.9] "Investment in Latin America Restrained," West Europe Economic Review, 7, FBIS-WEU-94-213-S, 95P20118B (November 3, 1994).

[3.10] Matt Moffett, "Brazil's Economic Policy Lacks Harmony," Wall Street Journal, A10 (April 12, 1995).

[3.11] Guilherme Ary Plonski, "The Need to Reconceptualize CAD: The Case of Brazilian Engineering Consultancy Firms," IEEE Trans. Eng. Man. 36 (4), 293-297 (November 1989).

[3.12] Guilherme Ary Plonski, "Government/Industry/Academic Partnerships in Brazil," Technology Management: The New International Language, eds. D. F. Kocaoglu and K. Niwa, (IEEE, NY, 1991), p. 582.

[3.13] DSSCS Message, VZCZCMSS4406, R041812Z, May 1995.

[3.14] Zygmunt Rozewicz, "Engineering Management in Poland: Problems of Systems Change," Technology Management: The New International Language, eds. D. F. Kocaoglu and K. Niwa, (IEEE, NY, 1991) pp. 789-793.

[3.15] Dana Milbank, "Polish Entrepreneurs Revitalize Economy but Battle Huge Odds," The Wall Street Journal (March 30, 1995).

[3.16] "Recent Trends and Policy Measures in the Countries of Central and Eastern Europe," Industrial Policy in OECD Countries: Annual Review 1994 (OECD, Paris, 1994), pp. 157-196.

[3.17] Janusz K. Kowlaski, "Ever More Small Firms: State Policy Should Be Better Geared Toward Supporting the Development of Enterprise," FBIS-EEU-95-102, 37-39 (May 26, 1995). 
[3.18] Louisa Vinton, "This engine needs no driver," Business Eastern Europe (March 13, 1995), p. 5.

[3.19] Jan Szomburg and Jacek Mach, Economic Successes in Past Five Years Eyed, Glos Wybrezeza, Gdansk, May 22, 1995 [MM0206103095 translated in FBIS-EEU-95-106, 38-41 (June 2, 1995).]

[3.20] Piotr Anrzejewski, "The Geography of Risk," Sprost, Poznan, April 16, 1995 [95EP0097B translated in FBIS-EEU-95-104, 56-57

(May 31, 1995) .]

[3.21] Janusz Filipiak \& Andrzej R. Pach, "Engineering Education in Poland," IEEE Comm. Mag., 58-64 (November 1992).

[3.22] Ewa Nowakowska, "The Paymaster of Brains," Polityka, \#12, 20 (March 25, 1995) [translated in FBIS-EEU-95-099, 48-50 (May 23, 1995).]

[3.23] Bozena Kastory, "The Price of Thinking," Sprost, \#22, Poznan, 65-66 (May 28, 1995) [95EP0134A translated in FBIS-EEU-95-155, 57-58 (August 11, 1995).]

[3.24] "Tired of capitalism? So soon?," The Economist, 61-62 (January 21, 1995).

[3.25] Economic Indicators of Taiwan, American Institute in Taiwan, Taipei, Taiwan, January 1995.

[3.26] New Economic Partners: Dynamic Asian Economies and Central and Eastern European Countries (OECD, Paris, 1994).

[3.27] Ashoka Mody, Staying in the Loop: International Alliances for Sharing Technology, World Bank Discussion Paper No. 61, 1989.

[3.28] "Recent Trends and Policy Measures in the Newly-Industrialized Economies of Asia," Industrial Policy in OECD Countries, 173-187, Annual Review, 1994.

[3.29] Alfred Rosenblatt and Tekla S. Perry, "Formula for Competitiveness," IEEE Spectrum 28 (6), 49-62 (June 1991).

[3.30] Julian Baum, "Home Sweet Home," Far Eastern Economic Review, 66-68 (September 29, 1994).

[3.31] Research-Technology Management, November-December 1993, pp. 5-6. [excerpted from Human Resources for Science and Technology: The Asian Region, National Science Foundation Report No. 93-303.]

[3.32] Lin-shan Lee, "Taiwan: Meeting the New Challenges," IEEE Comm. Mag., 18-26 (November, 1992).

[3.33] "Taiwan: The Outsider," The Economist, 17-19 (July 2, 1994).

[3.34] Narendra Aggarwal, "Singapore Lags Rivals in R\&D Spending," The Straits Times (May 1995).

[3.35] Bob Johnstone, "Past Success Provides No Sure Guide to the Future," Science 262, 358-360 (October 15, 1993). 
[3.36] Tong B. Tang, "Science and Technology in Taiwan," Science and Technology in China (Longman, UK, 1984), pp. 201-216.

[3.37] Chang Li, "National Science Council R\&D Plans," National Science Council Monthly 22 (2), 103-104 (February 1994) [946B0085A translated in JPRS-CST-94-015, 1-21 (September 20, 1994).]

[4.1] Peter O'Brien and Yannis Karmokolias, Radical Reform in the Automotive Industry: Policies in Emerging Markets, International Finance Corporation Discussion Paper No. 21, (The World Bank, Washington, DC, 1994).

[4.2] Country Commercial Guides. U.S. Department of Commerce, Washington, DC, 1995.

[4.3] Marco Piquini, The Motor Industries of South America and Mexico, The Economist Intelligence Unit, Research Report No. R325, U.K., 1995.

[4.4] Wendy Tien, Correspondence, American Institute in Taiwan Trade Center, Taipei, Taiwan, October 1995.

[4.5] Edward Pincheson and Michael Wooller, The East European Automotive Sector, 1994 Edition. The Economist Intelligence Unit, Research Report No. R315, U.K., 1994.

[4.6] "Nissan Proposes China Car-Parts Venture: Partners Would Include Taiwanese Unit," The Nikkei Weekly, 19 (July 17, 1995).

[4.7] Wendy Tien, The Passenger Cars Market in Taiwan, American Institute in Taiwan, Taipei, August 1994 [in the National Trade Data Bank, IT Market 111087649, Department of Commerce, Washington, D.C.]

[4.8] Correspondence with the Office of Automotive Affairs, Department of Commerce, Washington, D.C., 1995.

[4.9] Wong Poh Kam, Technological Development Through Subcontracting Linkages. Asian Productivity Organization, 1991.

[4.10] George F. Ray, The Diffusion of Mature Technologies (Cambridge University Press, Cambridge, 1984).

[4.11] Erik J. de Bruijn and Zianfeng Jia, Transferring Technology to China by Means of Joint Ventures," Res. Tech. Man., 17-22 (JanuaryFebruary 1993).

[4.12] Michael Moynihan and Ronald S. Jonash, Leveraging Technology in the New Global Company, The Economist Intelligence Unit, Research Report No. I-117, 1993.

[5.1] The World Competitiveness Report 1994. IMD and WEF, Switzerland, ISBN 2-88149-015-8, September 1994.

[5.2] "Emerging Market Indicators," The Economist, 124 (February 19, 1994); 120 (May 21, 1994); 106 (December 17, 1994); 106 (March 4, 1995); 106 (May 13, 1995).

[5.3] World Investment Report 1994: Transnational Corporations, Employment, and the Workplace (United Nations, NY, 1994). 
[5.4] "Economic Indicators" The Economist, 69 (April 2, 1994); 102 (October 1, 1994).

[5.5] Country Commercial Guides (U.S. Department of Commerce, Washington, DC, February 1995).

[5.6] Country Economic Policy and Trade Practices (U.S. Department of State, Washington, DC, February 1994).

[5.7] 'Symposium on the Globalization of Industry: Government and Corporate Issues," Industrial Policy in OECD Countries, Annual Review 1994 (OECD, Paris, 1994), pp.157-196. 


\section{List of Acronyms}

E.U. European Union

FDI Foreign Direct Investment

GDP Gross Domestic Product

GNP Gross National Product

LAP Low Average Productivity

MNE Multinational Enterprises

NIS Newly Independent States

OECD Organization of Economic Cooperation and Development

R\&D Research and Development

SME Small- and Medium-Sized Enterprises

SOE State-Owned Enterprises and State Treasury-Owned Companies 
